

\section{Sumário}

I. Crônicas do Direito Internacional ...............................................1

REPARAÇÃo DE VÍTIMAS À LUZ DE UM TRATAdo SOBRE EMPRESAS E DIREITOS HUMANOS ............ 3 Ana Cláudia Ruy Cardia

Consumer Social Responsibility as a Requirement for Corporate Social ResponsibiliTY

Nitish Monebhurrun

Crisis in Venezuela: The Brazilian response to the massive flow of Venezuelans in

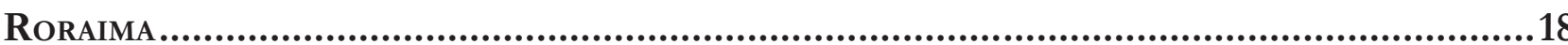

Jacqueline Salmen Raffoul

II. Dossiê EsPecial: Business and Human Rights.........................................23

Some remarks on the third sessions of the Business and Human Rights Treaty Pro-

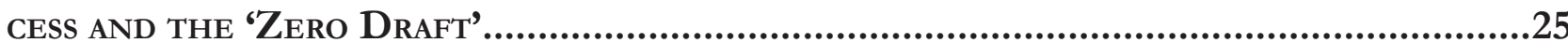

Humberto Cantú Rivera

The United Nations guiding principles on business and human Rights, the State

DUTY TO PROTECT HUMAN RIGHTS AND THE STATE-BUSINESS NEXUS.

Mihaela Maria Barnes

HARdening SOFT LAW: ARE THE EMERging Corporate SOCIAL DisClOSURE LAWS CAPABLE OF GENERATING SUBSTANTIVE COMPLIANCE WITH HUMAN RIGHTS?

Justine Nolan

Del Documento de Elementos al Draft 0: apuntes jurídicos respecto del posible CONTENIDO DEL PROYECTO DE INSTRUMENTO VINCULANTE SOBRE EMPRESAS TRANSNACIONALES

Y OTRAS EMPRESAS CON RESPECTO A LOS DERECHOS HUMANOS

Adoración Guamán 
ACCESS TO REMEDIES AND THE EMERGING ETHICAL DILEMMAS: CHANGING CONTOURS WITHIN THE BUSINESS-HUMAN RIGHTS DEBATE

Justin Jos

LA RESPONSABILIDAD PENAL DE LAS EMPRESAS POR GRAVES VIOLACIONES DE DERECHOS HUMANOS: PRÁCTICA ACTUAL Y DESAFÍOS FUTUROS 130

Daniel Iglesias Márquez

THE ENVIRONMENTAL LAW DIMENSIONS OF AN INTERNATIONAL BINDING TREATY ON BUSINESS AND HUMAN RIGHTS

Juan Gabriel Auz Vaca

Los Objetivos de Desarrollo Sostenible en Europa y su Intersección con el Marco de los Negocios y los Derechos Humanos

Paolo Davide Farah

HumAN RIGHTS AND MARKET ACCESS 203

Danielle Mendes Thame Denny

BusinesS AND HUMAN RIGHTS IN BRAZIL: EXPLORING HUMAN RIGHTS DUE DILIGENCE AND OPERATIONAL-LEVEL GRIEVANCE MECHANiSMS IN THE CASE OF KinRoss PARACATU Gold Mine...222 Mariana Aparecida Vilmondes Türke

Human Rights and eXtractive industries in Latin America: What Responsibility of CORPORATIONS AND THEIR STATES OF ORIGIN FOR HUMAN RIGHTS VIOLATIONS IN THE INTER-American Human Rights System?.

Alberto do Amaral Junior e Viviana Palacio Revello

MultinaCiOnAIS FAST FASHION E DIREITOS HUMANOS: EM BUSCA DE NOVOS PADRÕES DE RESPONSABILIZAÇÃO 255

Laura Germano Matos e João Luis Nogueira Matias

III. Artigos sobre outros temas

EFFICIENCY AND EFFICACY OF PUBLIC FOOD PROCUREMENT FROM FAMILY FARMERS FOR SCHOOL FEEDING IN BRAZIL. 271

Rozane Márcia Triches 
A relaÇão ENTRE O GRAU de INTEGRaÇÃo ECONÔMiCA E O SISTEMA DE SOLUÇÃo DE CONTROvÉRSIAS: UM ESTUdo COMPARATIVO ENTRE A UNIÃo EURopeia E O MERCOSUl.....................286

Luciane Klein Vieira e Elisa Arruda

THE RIGHTS TO MEMORY AND TRUTH IN THE INTER-AMERICAN PARADIGMS OF TRANSITIONAL JUSTICE: THE CASES OF BRAZIL AND CHILE 308

Bruno Galindo

Juliana Passos de Castro

A margem nacional de apreciação na Corte Interamericana de Direitos Humanos.325 Gilberto Schäfer, José Eduardo Aidikaitis Previdellie e Jesus Tupã Silveira Gomes

Novos Direitos FUNDAMENTAIS NO ÂMBITo DA UNASUL: ANÁLISE DAS AGENDAS DE Brasil E VENEZUELA À LUZ DO DIREITO À PAZ.

Pedro Pulzatto Peruzzo e Arthur Ciciliati Spada

A atuação do Grupo Mercado Comum frente À Criminalidade organizada transnacio-

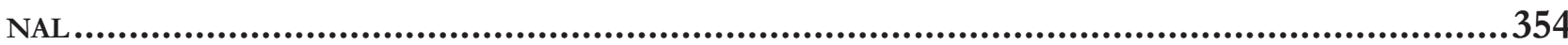

Sabrina Cunha Kesikowski, Luis Alexandre Carta Winter e Eduardo Biacchi Gomes

COUNTER-TERRORISM LEGISLATION AND TERRORIST ATTACKS: DOES HUMAN RIGHTS HAVE SPACE?

Heloisa Tenello Bretas e Daniel Damásio Borges

Territórios da ViolênCia de GÊNERo: NORMATIVA INTERNACIONAL E os Casos "CAMpo AlGodoeiro” (MÉXICO) - “Morro do Garrote” (BrasiL)

Eugênia Nogueira do Rêgo Monteiro Villa e Bruno Amaral Machado

O USO DE MECANISMOS INFORMAIS DE GOVERNANÇA GLOBAL E SUA APLICABILIDADE NAS LICITAÇÕES PÚBLICAS BRASILEIRAS.

Fabiano de Figueiredo Araujo e Paulo Afonso Cavichioli Carmona

Autonomia INSTITUCIONAL DA IGREJA CATÓliCA E A INGERÊNCIA INDEVIDA DO ESTADO BRASILEIRo POR EVENTUAIS Ilícitos CANÔNicos: ANÁlise do CASO de Formosa-GO, À luz do TraTADo Brasil-Santa SÉ de 2010 
A MORE TARGETED APPROACH TO FOREIGN DIRECT INVESTMENT: THE ESTABLISHMENT OF SCREENING SYSTEMS ON NATIONAL SECURITY GROUNDS

Carlos Esplugues Mota

IV. RESENHAS 467

Direito Internacional em Perspectiva Transcivilizacional de Yasuaki Onuma........469 Arthur Roberto Capella Giannattasio

Resenha do livro Space, Global Life: The Everyday Operation of International LaW and Development, de Luis Eslava .473

Matheus Gobbato Leichtweis

QUEM TEM MEDO DO PÓS-COLONIAL NO DIREITO INTERNACIONAL? UMA RESENHA DE "DECOLONISING INTERNATIONAL LAW: DEVELOPMENT, ECONOMIC GROWTH AND THE POLITICS OF UNIVERSAlity" de Sundhya Pahuja

Gabriel Antonio Silveira Mantelli

Direitos humanos COMO UM NOVO PROJETO PARA O Direito INTERNACIONAL? Notas sobre The Last Utopia, de Samuel Moyn .490 João Roriz 


\title{
A relação entre o grau de integração econômica e o sistema de solução de controvérsias: um estudo comparativo entre a União Europeia e o Mercosul*
}

\author{
The relationship between the degree of \\ economic integration and the dispute \\ settlement system: a comparison study \\ between the European Union and Mercosur
}

Luciane Klein Vieira**

Elisa Arruda***

\section{Resumo}

A formação de blocos econômicos no cenário internacional é uma resposta ao fenômeno da globalização, fazendo com que Estados atuem, conjuntamente, para fortalecer interesses comuns. A partir da integração regional, que aproxima os Estados signatários do tratado constitutivo, forma-se um novo ordenamento jurídico, que deve estar dotado de um sistema de solução de controvérsias. Na União Europeia, há o Tribunal de Justiça, instituição supranacional, que, além de dirimir conflitos, tem como função uniformizar o Direito da União no território intra bloco, por meio da questão prejudicial. Já o MERCOSUL, cujo sistema é intergovernamental, detém um sistema de pacificação de controvérsias de natureza arbitral, cuja instituição máxima é o Tribunal Permanente de Revisão. Por meio do estudo comparativo entre os sistemas de solução de controvérsias de cada um dos blocos, verificou-se a existência de uma relação direta destes com o nível de integração econômica entre os Estados participantes, na medida em que, quanto mais profunda é a integração econômica, mais desenvolvido será o processo de solução de conflitos. A partir da conclusão referida e considerando-se as diferenças históricas, socioeconômicas e políticas que circundam cada bloco, o presente artigo analisou possibilidades para o fortalecimento do Tribunal do MERCOSUL, sobretudo no que diz respeito a sua competência não contenciosa, exercida por meio das opiniões consultivas. Para o desenvolvimento do trabalho, que se destina a fornecer ferramentas para a consolidação do MERCOSUL jurídico, foi utilizado o método normativo descritivo, com pesquisa de cunho qualitativo.

Palavras-chave: Direito da integração. Solução de controvérsias. União Europeia. MERCOSUL. Questão prejudicial. Opinião consultiva. contratada pelo Programa das Nações Unidas para o Desenvolvimento (PNUD).

E-mail: lucianekleinvieira@yahoo.com.br
*** Advogada, com atuação em Lisboa, na área de contratos internacionais desportivos. E-mail: earruda9@gmail.com 


\section{Abstract}

The development of trade blocs on an international level is a response to the phenomenon of globalization, causing States to act together with the aim of strengthening common interests. With regional integration as a starting point, a new legal system is formed upon the constituent treaty, thus requiring its own dispute resolution mechanism. In the European Union, there is the Court of Justice, a supranational institution with the purpose of not only settling disputes, but also unifying Union's law within its territory, by way of preliminary rulings. In MERCOSUR, where the structure is intergovernmental, the dispute resolution system is arbitral in nature, with the Permanent Revision Court as its highest institution. Through a comparative study of the dispute resolution systems of each bloc, a direct relationship between these and the level of economic integration among the participating States was detected, insofar as the deeper the economic integration, the more effective the conflict resolution process. Based on this conclusion and considering the historical, socioeconomic and political differences that surround each block, this article analyzed possibilities for the strengthening of the MERCOSUR Court, especially with regard to its non-litigious jurisdiction, exercised through the issuance of consultative opinions. For the development of the present work, which is intended to provide tools for the consolidation of the legal MERCOSUR, the normative descriptive method was used, with a qualitative research.

Keywords: Integration law. Dispute settlement. European Union. MERCOSUR. Preliminary ruling. Consultative opinion.

\section{INTRODUÇÃo}

O cenário internacional em que se relacionam os Estados e organizações internacionais não é uma realidade estática. Ao contrário: à medida em que o fenômeno da globalização se intensifica, avança, também, o fenômeno da regionalização, ${ }^{1}$ que se constitui na formação de blocos econômicos entre Estados que desejam atuar em

1 Sobre o tema da globalização e seus efeitos sobre a constituição dos sistemas jurídicos, ver: NASSER, Salem Hikmat. Direito global em pedaços: fragmentação, regimes e pluralismo. Revista de Direito Internacional UNICEUB, v. 12, n. 2, p. 98-137, 2015. conjunto, movidos por interesses em comum. No interior desses novos players, surge um ordenamento jurídico, que se destina a regular as relações entre os próprios Estados, mas que, também, alcança e atua no cotidiano dos indivíduos abarcados pela integração ${ }^{2}$.

Partindo-se da premissa de que, no desenvolvimento da integração regional, é natural que surjam eventuais conflitos, é imprescindível contar com um sistema de solução de controvérsias. Desse modo, em que medida as características da supranacionalidade ${ }^{3}$ ou da intergovernamentalidade ${ }^{4}$, aliadas ao objetivo econômico dos Estados integrados, influenciam na maneira como são solucionadas as controvérsias que surgem em determinado bloco econômico?

Como hipótese central, esperava-se verificar uma relação de causa e efeito entre o aprofundamento da integração econômica e o consequente desenvolvimento de seu sistema de solução de controvérsias, levando em consideração a característica supranacional do Tribunal de Justiça da União Europeia (TJ/UE), em estudo comparativo ao contexto do Mercado Comum do Sul (MERCOSUL), marcado pela intergovernamentalidade.

2 Esse novo ordenamento jurídico adota um sistema normativo e institucional próprio, cujo processo decisório baseia-se na transferência do exercício de poderes e competências usualmente estatais. DIZ, Jamile Bergamaschine Mata; JAEGER JUNIOR, Augusto. Por uma teoria jurídica da integração regional: a inter-relação direito interno, direito internacional público e direito da integração. Revista de Direito Internacional UNICEUB, v. 12, n. 2, p. 138-158, 2015.

3 A supranacionalidade caracteriza toda a configuração e modo de atuação do sistema de integração da União Europeia. Dessa forma, três são os pilares que sustentam os sistemas nela pautados, a saber: a) a transferência de soberania dos Estados para o bloco regional em caráter definitivo; b) a supremacia do Direito produzido em relação aos direitos nacionais; e c) a dimensão teleológica de integração, que é a supranacionalidade para alcançar os fins integracionistas. CICCO FILHO, Alceu José; LAGE, Fernanda Carvalho; ROCHA, Maria Elizabeth Guimarães Teixeira. O Tribunal Permanente de Revisão do MERCOSUL: intergovernamentalidade e desafios à supranacionalidade. International Studies on Law and Education, São Paulo, v. 1, p. 55-70, set./dez. 2016.

4 Em um contexto de intergovernamentalidade, “...o interesse predominante é resultado da vontade individual de cada EstadoMembro, não de estrutura institucional independente destes, e as normas jurídicas devem ser submetidas aos processos de internalização previstos nos textos legislativos de cada País, em geral, suas Constituições Federais. Não se fala em aplicabilidade imediata das normas emanadas das instituições e tampouco em primazia frente aos ordenamentos jurídicos nacionais". SALDANHA, Jânia Maria Lopes. Cooperação Jurisdicional: reenvio prejudicial: um mecanismo de direito processual a serviço do direito comunitário: perspectiva para sua adoção no MERCOSUL. Porto Alegre: Livraria do Advogado, 2001. p.110. 
Nesse contexto, em um primeiro momento, aborda-se a origem da integração regional e as principais características da União Europeia (UE) e do MERCOSUL. Em seguida, são analisados o TJ/UE, bem como a evolução do sistema do MERCOSUL, que conta com o Tribunal Permanente de Revisão (TPR), desde 2005.

Ato contínuo, são analisadas as questões prejudiciais enquanto instrumentos de uniformização do ordenamento jurídico regional, bem como os principais leading cases europeus, decididos em sede prejudicial, que contribuíram para a formação das bases do Direito da União. São apontadas as diferenças entre a questão prejudicial do TJ/UE e a opinião consultiva do TPR, bem como entre as próprias instituições. Finalmente, formulam-se sugestões pontuais para o avanço do sistema de solução de controvérsias do MERCOSUL, com base na análise das opiniões consultivas havidas, sem, contudo, olvidar que seu contexto histórico, socioeconômico e político lhe é próprio, sendo impossível e mesmo indesejável transplantar as soluções da integração europeia.

\section{A INTEGRAÇão Regional POR MEIO DE bLocos ECONÔMICOS E SEUS PARADIGMAS JURÍDICOS}

A integração entre Estados, sobretudo aquela com objetivos econômicos, não se dá por meio de um processo rápido ou automático, mas sim por meio de uma paulatina evolução da relação jurídica estabelecida entre os signatários do tratado marco, criador do bloco econômico.

Nesse ínterim, a fim de elucidar os objetivos de natureza econômica que deram vazão à criação da UE e do MERCOSUL, apresentam-se esses processos de integração regional, contextualizando-os nas características da supranacionalidade e da intergovernamentalidade, conforme o caso.

\subsection{A União Europeia: objetivo econômico e supranacionalidade}

A integração iniciou-se no continente europeu ainda em meados da década de 1940, logo após a II Guerra Mundial, tendo nascido da necessidade da reconstrução de uma Europa devastada. Já na década de 1950, coexis- tiam três iniciativas ${ }^{5}$, que, ao evoluírem, formam o que hoje é a UE.

Nesse cenário, o Direito criado pelo bloco, por meio de suas instituições, para reger as relações entre os Estados Membros e os particulares, funda-se na supranacionalidade, característica gerada da cessão de parte da soberania estatal, especialmente em matéria legislativa, a uma organização internacional cuja existência jurídica é própria e separada dos Estados — surge aqui a UE, ${ }^{6}$ assim denominada desde a entrada em vigência do Tratado de Maastricht, firmado em $1992 .^{7}$

Aqui, cabe realçar que o conceito de supranacionalidade reside a meio caminho entre o individualismo internacional (que tem a soberania estatal como intangível) e uma federação de Estados (subordinação a um superestado), segundo lecionam Campos e Campos, citando o pensamento de Robert Schuman, ${ }^{8}$ um dos precursores da ideia da integração europeia.

Por outro lado, com relação aos objetivos econômicos e como decorrência da supranacionalidade, é de se destacar que, desde 1992, a UE, que já havia transitado pelas etapas econômicas anteriores da zona de livre comércio e união aduaneira, obteve a consolidação do mercado comum, que se caracteriza pela obtenção das quatro liberdades de circulação (de mercadorias, serviços, pessoas e investimento estrangeiro). Atualmente, o bloco encontra-se na etapa da comunidade econômica, tendo estabelecido políticas monetárias e macroeconômicas comuns, estando agora a caminho de uma efeti-

5 Naquela altura, existiam a CECA (Comunidade Europeia do Carvão e do Aço) e a CEE (Comunidade Econômica Europeia), criadas pelo Tratado de Paris de 1951, bem como a EURATOM (Comunidade Europeia de Energia Atômica), criada pelo Tratado de Roma de 1957. Na atualidade, a CECA, após 50 anos de existência, deixou de existir, por determinação expressa do tratado constitutivo e a CEE foi substituída pela UE. A EURATOM continua existindo, nos termos em que concebida, em 1957.

6 Cabe destacar que a UE está formada, atualmente, por 28 Estados Membros, a saber: Alemanha, Áustria, Bélgica, Bulgária, Chipre, Croácia, Dinamarca, Eslováquia, Eslovênia, Espanha, Estônia, Finlândia, França, Grécia, Hungria, Irlanda, Itália, Letônia, Lituânia, Luxemburgo, Malta, Países Baixos, Polônia, Portugal, Reino Unido, República Checa, Romênia, Suécia.

7 A UE tem suas competências, mecanismos, ferramentas e funcionamento elencados nos Tratados constitutivos, a saber: Tratado da União Europeia e Tratado de Funcionamento da União Europeia, em versão atualizada e reorganizada pelo Tratado de Lisboa, em 2009.

8 CAMPOS, João Mota de; CAMPOS, João Luiz Mota de. Manual de direito europeu: o sistema institucional, a ordem jurídica e o ordenamento económico da União Europeia. 6. ed. Coimbra: Wolters Kluwer, 2010. p. 259. 
va integração monetária, que estará alcançada quando todos os Estados Membros adotem uma moeda única (euro) e se submetam ao Banco Central Europeu.

No que diz respeito à solução de controvérsias, $\mathrm{O}$ TJ/UE demonstra-se imprescindível à integração europeia, uma vez que, por meio de sua jurisprudência, consolidaram-se princípios essenciais ao Direito da União, como a própria noção de supranacionalidade, o princípio da primazia do Direito da UE, do efeito direto e da aplicabilidade imediata de suas normas.

\subsection{O MERCOSUL: objetivo econômico e intergovernamentalidade}

A América Latina, contexto em que, contemporaneamente, se desenvolve o MERCOSUL, foi palco de uma história marcada por profundas desigualdades, pela colonização ibérica e por ditaduras militares. Somente após a redemocratização da região, nas últimas décadas do século XX, se revigorou a vontade política voltada à integração, alinhada às perspectivas de benefícios mútuos e de maior inserção na ordem global.

No ano de 1980, foi criada a Associação Latino-Americana de Integração - ALADI, sucessora da anterior tentativa de integração econômica, da década de 60, denominada ALALC, ${ }^{9}$ - organização de grande importância para o MERCOSUL. O Tratado de Assunção ${ }^{10}$, documento que marca a gênese do MERCOSUL, em 1991, prevê a possibilidade de adesão ao bloco originalmente formado por Argentina, Brasil, Paraguai e Uruguai, por outros Estados membros da ALADI. Por meio dessa cláusula de adesão, se deu o conturbado ingresso da Venezuela, no ano de 2012, e, mais recentemente, em 2015, o da Bolívia - esse último, ainda, em fase de implementação.

Apesar de seu ambicioso nome - Mercado Comum do Sul, não se verifica a presença das quatro liberdades que

9 A Associação Latino-Americana de Livre Comércio - ALALC, criada pelo Tratado de Montevidéu de 1960, tinha um objetivo econômico mais ambicioso que a ALADI, e este foi apontado como sendo um dos motivos do seu fracasso. Em 12 anos, a contar da sua fundação, os países integrantes deveriam ter consolidado uma zona de livre comércio, que abarcasse somente a circulação de bens, o que finalmente não ocorreu.

10 Internalizado pelo direito brasileiro através do Decreto $\mathrm{n}^{\circ} 350$, de 21 de novembro de 1991, que Promulga o Tratado para a Constituição de um Mercado Comum entre Argentina, Brasil, Paraguai e Uruguai. Disponível em: <http://www.planalto.gov.br/ccivil_03/ decreto/1990-1994/D0350.htm>. Acesso em: 20 mar. 2017. marcam um mercado comum, ligadas à irrestrita circulação de mercadorias, pessoas, serviços e capitais. Assim, o bloco pode ser caracterizado como uma união aduaneira imperfeita, pois, apesar da existência de uma Tarifa Externa Comum - TEC ${ }^{11}$, denominada Nomenclatura Comum do MERCOSUL, que harmoniza a classificação tarifária dos produtos provenientes de terceiros Estados, a conformação dessa etapa aduaneira está prejudicada por Listas de Exceções ${ }^{12}$, cuja existência se prolonga no tempo.

Com relação à sua principal característica, que revela um menor compromisso com a integração regional, o MERCOSUL se estrutura por meio da intergovernamentalidade, pois seus Estados Partes conservam intactas suas soberanias, relacionando-se por meio dos mecanismos criados pelo Direito Internacional Público clássico $^{13}$.

Nesse caso, inexiste qualquer delegação de competências pelo Estados Partes ao bloco, ${ }^{14}$ que se revela pela imprescindibilidade do consenso para a tomada de decisões ou mesmo para a produção normativa, que, posteriormente, deverá submeter-se ao procedimento de internalização em cada Estado Parte. Além disso, não há que falar em efeito direto ou aplicabilidade imediata das normas produzidas no contexto do bloco, uma vez que as mesmas devem, primeiramente, superar os procedimentos comuns de internalização à ordem jurídica interna dos Estados Parte, para somente então surtirem efeito.

No bloco, a instituição responsável pela harmonização da interpretação e aplicação do Direito do MER-

11 A TEC é a "Nomenclatura Comum do MERCOSUL" (NCM), adotada através da Decisão CMC no 22, de 1994 (e modificações). É uma técnica de classificação fiscal-aduaneira uniformizada dentro do território integrado, que atribui a cada mercadoria um código relacionado às suas características. A partir desta harmonização da classificação fiscal-aduaneira, é possível assegurar que mercadorias da mesma natureza recebam tratamento equivalente dentro do MERCOSUL.

12 Os Estados Partes do MERCOSUL mantêm Listas de Exceções à TEC, contendo um número determinados de itens da NCM, temporariamente excetuados do regime geral, mediante aprovação do CMC. Seu objetivo é atenuar problemas de disparidades econômicas, devendo ser gradualmente eliminadas na medida em que se operacionalize a convergência do bloco econômico.

13 KEGEL, Patrícia Luíza; AMAL, Mohamed. Instituições, direito e soberania: a efetividade jurídica nos processos de integração regional nos exemplos da União Europeia e do MERCOSUL. Revista Brasileira de Política Internacional, Brasília, v. 52, n. 1, p. 53-70, 2009.

14 GOMES, Eduardo Biacchi. Blocos econômicos: solução de controvérsias. 3. ed. Curitiba: Juruá, 2010. p. 117. 
COSUL é o Tribunal Permanente de Revisão, órgão arbitral de convocatória permanente, cuja sede é em Assunção, no Paraguai, estando composto na atualidade por 5 árbitros. O TPR, em que pese tenha uma tímida atuação desde a sua criação pelo Protocolo de Olivos, firmado em 2002, exerce uma função de crucial importância para o aprofundamento da integração e, por esse motivo, merece especial destaque neste artigo.

\section{Sistemas de SOlução de CONTROVÉrsias DOS BLOCOS ECONÔMICOS}

A UE e o MERCOSUL, enquanto ordenamentos jurídicos com existência distinta daqueles de seus respectivos membros, necessitam de mecanismos próprios de solução de controvérsias, uma vez que a harmonização da interpretação e aplicação de seu arcabouço jurídico, além de sua efetividade em todo o território integrado, dependem de uma estrutura capaz de dirimir os conflitos que eventualmente surjam intra bloco.

A UE conta com o TJ/UE, já referido, instituição jurisdicional que detém competências delimitadas em seus tratados constitutivos e cujo objetivo precípuo é uniformizar a interpretação do ordenamento jurídico do bloco. ${ }^{15} \mathrm{O}$ indivíduo tem papel de protagonismo na integração europeia, na medida em que, em determinadas situações, possui legitimidade ativa para acionar diretamente o TJ/UE, na busca da realização de seus direitos individuais decorrentes do processo regional.

Já o MERCOSUL, enquanto bloco de formação mais recente e pautado pela intergovernamentalidade, possui um sistema de solução de controvérsias ainda provisório. ${ }^{16}$ Em seu contexto, predomina o caráter arbitral em detrimento de um sistema tradicionalmente jurisdicional, com restrição de acesso aos indivíduos.

15 Cf. intelecção do art. $19^{\circ}$ do TFUE, que trata desta instituição. Disponível em: <http://eur-lex.europa.eu/legal-content/PT/ TXT/PDF/?uri=OJ:C:2016:202:FULL\&from=PT>. Acesso em: 24 abr. 2017.

16 Cf. intelecção do art. 53 do Protocolo de Olivos. Segundo a doutrina: "cumpre observar que o sistema de solução de controvérsias estabelecido pelo Protocolo de Olivos é uma reformulação do sistema anterior e não se trata do sistema definitivo, que deverá ser adotado quando da culminação do processo de convergência da tarifa externa comum, a TEC." GOMES, Eduardo Biacchi. Protocolo de Olivos: alterações no sistema de soluções de controvérsias do MERCOSUL e perspectivas. Revista da Faculdade de Direito UFPR, Curitiba, v. 37, p. 163, 2002.
O Tratado de Assunção já previa uma forma simplificada e provisória de pacificação de conflitos relacionados à integração: os Estados Partes envolvidos em uma controvérsia deveriam realizar negociações diretas, e, em caso de insucesso, haveria mediação pelo Grupo Mercado Comum (GMC) e, em última instância, atuava o Conselho do Mercado Comum (CMC), órgão com carácter decisório e detentor da personalidade jurídica do bloco.

Já o Protocolo de Brasília sobre solução de controvérsias, firmado ainda em 1991, manteve as negociações diplomáticas diretas e o recurso ao GMC, mas introduziu uma importante alteração no método a ser utilizado pelos Estados, para obter a pacificação do conflito. Nesse sentido, passou a prever a formação de tribunais arbitrais ad hoc, compostos por 3 árbitros, utilizados, apenas, em caso de insuficiência da negociação e mediação anteriormente reportadas, inexistido uma instituição arbitral com carácter permanente. Pela norma em comento, foi eliminada a participação do CMC como última instância responsável pela solução do conflito, na medida em que foi substituída pela participação dos tribunais ad hoc, cujas decisões, chamadas de laudos arbitrais, passaram a ser obrigatórias e vinculantes.

Em 2002, com a assinatura do Protocolo de Olivos, o sistema de solução de controvérsias avançou por meio da criação de um órgão de caráter não provisório: o Tribunal Permanente de Revisão (TPR), que se instalou na cidade de Assunção, no Paraguai, em 2005. Ainda, o tratado passou a possibilitar às partes litigantes que fossem das negociações diplomáticas diretamente à instância arbitral, seja por meio do recurso aos tribunais arbitrais ad hoc ou diretamente ao TPR, obviando, se assim quisessem, a mediação pelo GMC. ${ }^{17}$

Dadas as suas competências e características institucionais, o papel que o TPR desempenha no desenvolvimento da integração, no MERCOSUL, é radicalmente diferente daquele do TJ/UE, conforme será explorado a seguir.

17 Sobre o sistema de solução de controvérsias do MERCOSUL, ver: NEGRO, Sandra C.; VIEIRA, Luciane Klein. Transformaciones en la integración regional: Venezuela y el sistema de solución de diferencias del MERCOSUR. In: ASTRID UZCÁTEGUI, María Inés de Jesús. Venezuela ante el MERCOSUR. Caracas: Academia de Ciencias Políticas y Sociales/Universidad de los Andes/Universidad Católica Andrés Bello, 2014. p. 189-206. v. 2. 


\subsection{O Tribunal de Justiça da União Europeia}

Desde a década de 1950, a integração europeia foi dotada de um sistema de solução de controvérsias dedicado à uniformização do Direito produzido pelo bloco. Nessa esteira, já em 1952, foi criado o que hoje é o TJ/ UE, uma das instituições mais significativas do bloco. O TJ/UE é composto por um juiz por Estado Membro e 11 advogados gerais. Caracteriza-se como tribunal permanente, com sede em Luxemburgo, cuja jurisdição está acima dos Estados Membros, proferindo decisões vinculantes, que, entre outros objetivos, buscam uniformizar o entendimento e a aplicação do arcabouço jurídico do Direito da União, de forma a garantir sua interpretação e aplicação harmônicas.

Dessa forma, sua competência prejudicial existe desde 1957, mantendo-se em essência a mesma até hoje o que pode ser verificado por meio da comparação do art. 177 do então Tratado Constitutivo da Comunidade Econômica Europeia (CEE) e o atualmente em vigor art. 267 do Tratado de Funcionamento da União Europeia (TFUE).

$\mathrm{O} \mathrm{TJ} / \mathrm{UE}$ evoluiu juntamente ao aprofundamento da integração entre os Estados Membros e o fortalecimento do bloco econômico. Mais do que isso, o Tribunal participa, contínua e ativamente, desse processo, através de decisões que moldaram o próprio Direito da União (por meio de acórdãos paradigmáticos, como Van Gend en Loos e Costa/ENEL, analisados a seguir, dentre outros). Assim, o reconhecimento da supranacionalidade, os princípios como o efeito direto e a aplicabilidade imediata do Direito europeu, além da primazia sobre os direitos nacionais, originaram-se justamente na jurisprudência do TJ/UE.

De acordo com os Tratados, o Tribunal é a instituição dotada de jurisdição e competência para dar a última palavra a respeito do Direito da UE, sua validade, interpretação e aplicação, em todo o território intra bloco - com o objetivo de assegurar sua plena efetividade, de acordo com os arts. $19^{\circ}$ e $267^{\circ}$ do Tratado da União Europeia (TUE) e do Tratado de Funcionamento da União Europeia (TFUE), respectivamente.

Dessa forma, verifica-se que o TJ/UE é um órgão verdadeiramente jurisdicional, dadas as características de independência (de outras instituições europeias e dos Estados-Membros), jurisdição própria e competência exclusiva em determinadas matérias. ${ }^{18}$

São relevantes ao objeto desde estudo a competência internacional (cumprimento ou não do direito europeu) e a constitucional, que trata da interpretação, validade e aplicação das normas europeias em função dos Tratados.

Nesse tocante, a jurisdição do TJ/UE desdobra-se em voluntária e contenciosa. A jurisdição contenciosa se relaciona ao descumprimento do Direito da União pelos órgãos e instituições da organização referida e seus Estados Membros, sendo, portanto, obrigatória e suas decisões, vinculantes. Já a jurisdição voluntária diz respeito a questões de interpretação do Direito da União, e de validade e compatibilidade dos atos dos órgãos e instituições em face dos tratados constitutivos ${ }^{19}$.

O procedimento consultivo de competência do TJ/ UE, denominado questão prejudicial, previsto no art. $267^{\circ}$ do TFUE, será abordado a seguir. Através desse mecanismo, é possível aos tribunais nacionais formularem consultas sobre o Direito do bloco ao TJ/UE, de modo que, por meio da cooperação horizontal ${ }^{20}$ entre as jurisdições, seja privilegiada a uniformização da interpretação e aplicação das normas da União.

Ressalta-se que não existe hierarquia entre o TJ/UE e os tribunais nacionais dos Estados Membros. Desse modo, o que existe são jurisdições com competências distintas: aos tribunais nacionais cabe julgar questões referentes a seu respectivo direito nacional, devendo, também, submeter-se ao Direito europeu e aplicá-lo quando pertinente. Já a jurisdição do TJ/UE é competente para dar a última palavra a respeito do Direito da UE, sendo-lhe vedado imiscuir-se em questões de competência puramente nacional dos Estados Membros.

É interessante destacar, nesse contexto, que o indivíduo tem legitimidade ativa perante o sistema de solução de controvérsias europeu. É possível, por exemplo, que

18 CAMPOS, João Mota de; CAMPOS, João Luiz Mota de. Manual de direito europeu: o sistema institucional, a ordem jurídica e o ordenamento económico da União Europeia. 6. ed. Coimbra: Wolters Kluwer, 2010. p. 153.

19 CAMPOS, João Mota de; CAMPOS, João Luiz Mota de. Manual de direito europen: o sistema institucional, a ordem jurídica e o ordenamento económico da União Europeia. 6. ed. Coimbra: Wolters Kluwer, 2010. p. 191.

20 VIEIRA, Luciane Klein. Interpretação e aplicação uniforme do direito da integração: União Europeia, Comunidade Andina, Sistema da Integração Centro-Americana e MERCOSUL. Curitiba: Juruá, 2013. p. 44 . 
um particular participe ativamente do controle do cumprimento das normas do Direito da União, podendo propor demandas diretamente ao TJ/UE, em determinadas situações previstas nos Tratados.

\subsubsection{Ações de competência do TJ/UE e a ques- tão prejudicial}

Em um parêntese comparativo entre a jurisdição do TJ/UE e o Supremo Tribunal Federal brasileiro (STF), que visa auxiliar a compreensão do sistema de solução de controvérsias europeu, serão analisadas sucintamente as ações passíveis de submissão à sua jurisdição. Vejamos.

O Recurso de Anulação, cujo objetivo é controlar a legalidade de atos das demais instituições europeias, assemelha-se no plano interno brasileiro com a Ação Direta de Inconstitucionalidade, proposta diretamente perante o STF. Já o Recurso por Omissão objetiva levar uma instituição europeia a cumprir com uma determinação legal, de forma similar à Ação Direta de Inconstitucionalidade por Omissão brasileira. Existe, ainda, a Ação por Descumprimento, que visa compelir um Estado Membro à satisfação de determinação da União, guardando certo grau de similitude com mecanismos constitucionais brasileiros, a exemplo da Intervenção Federal em caso de desrespeito ao pacto federativo.

Como se percebe, apesar das semelhanças em sede de jurisdição constitucional, há uma diferença fundamental entre o sistema europeu e o controle de constitucionalidade do STF: o papel do indivíduo na administração da justiça.

O particular (pessoa individual ou coletiva) possui legitimidade ativa para propor algumas das ações mencionadas anteriormente, diretamente ao TJ/ $\mathrm{UE}^{21}$. Já na ordem interna brasileira, o indivíduo não possui legitimação ativa para a propositura de ações diretamente ao $\mathrm{STF}^{22}$, estando adstrito à arguição incidental, de maneira

21 Cf. o art. $263^{\circ}, \int 4^{\circ}$ e art. $265^{\circ}, \int 3^{\circ}$, ambos do TFUE. Com exceção da Ação por Incumprimento, contexto em que é necessária a representação do indivíduo primeiramente à Comissão Europeia, que, após uma fase administrativa prévia, poderá então levar o caso ao TJ/UE. Disponível em: < http:/ / eur-lex.europa.eu/legalcontent/PT/TXT/PDF/?uri=OJ:C:2016:202:FULL\&from=PT $>$. Acesso em: 24 abr. 2017.

$22 \mathrm{O}$ art. $103 \mathrm{da}$ CF traz o rol taxativo de legitimados à provocação do controle de constitucionalidade concentrado perante o STF. Além disso, o tribunal constitucional brasileiro restringiu ainda mais tal rol, por meio de sua jurisprudência, ao consolidar entendi- vinculada a seu caso concreto e perante as instâncias inferiores (controle de constitucionalidade difuso).

Encerra-se o parêntese comparativo com o controle de constitucionalidade brasileiro e retoma-se a análise unicamente do sistema de solução de controvérsias europeu.

A questão prejudicial, que se opera de maneira não contenciosa, é essencial à realização da missão do TJ/ $\mathrm{UE}$, pois permite que os juízes e tribunais dos Estados Membros - diante de um caso concreto - formulem consultas quanto à interpretação, aplicabilidade e validade das normas europeias. ${ }^{23}$ Como resultado, a decisão do TJ/UE, respondendo à consulta formulada, vincula não somente ao órgão jurisdicional consultante, senão a todos os órgãos jurisdicionais nacionais. Em outras palavras, o mecanismo possibilita garantir a segurança jurídica por meio da aplicação uniforme do Direito da UE.

Essa possibilidade de consultar o TJ/UE, antes de decidir o caso concreto, está disposta no art. $267^{\circ}$ do TFUE, que estabelece, ainda, a obrigatoriedade da consulta ao juiz nacional, quando a incerteza acerca da interpretação ou da validade do Direito europeu se der em única ou última instância. Sobre o tema, é importante frisar que:

Somente os juízes nacionais, pertencentes a um dos
Estados Membros do bloco, têm competência para
empregar este mecanismo processual. Isso significa
dizer que tampouco as partes, ainda que possam
sugerir ao juiz do litígio principal que proponha
ante o Tribunal de Justiça uma questão prejudicial,
tampouco o Estado e tampouco as instituições,
órgãos ou organismos da União estão autorizados
a utilizar este recurso. ${ }^{24}$

Sendo assim, os tribunais de última instância, diante de uma dúvida na interpretação do Direito da União a ser aplicado ao caso concreto ou diante de um caso que discute a validade do Direito referido, são obrigados a oferecer a questão prejudicial ao TJ/UE, estando dispensados dessa obrigatoriedade os juízes ou tribu-

mento de que determinados legitimados podem agir em caráter universal, enquanto outros somente podem fazê-lo se demonstrada a pertinência temática. Disponível em: <http://www.planalto.gov.br/ ccivil_03/constituicao/constituicaocompilado.htm>. Acesso em: 24 abr. 2017.

23 GOMES, Eduardo Biacchi. Blocos econômicos: solução de controvérsias. 3. ed. Curitiba: Juruá, 2010. p. 207.

24 VIEIRA, Luciane Klein. Interpretação e aplicação uniforme do direito da integração: União Europeia, Comunidade Andina, Sistema da Integração Centro-Americana e MERCOSUL. Curitiba: Juruá, 2013. p. 34-35. 
nais de inferior instância. Ainda, conforme destaca a doutrina, somente se o Tribunal comunitário já tiver se manifestado em sede prejudicial, em caso semelhante, os tribunais que deverão oferecer a consulta estarão dispensados dessa obrigação. Está-se, pois, ante a Teoria do Ato Aclarado. ${ }^{25}$

Dadas as características do sistema jurisdicional de solução de controvérsias da UE, consolidado pela atuação do TJ/UE, ressalta-se que a integração entre os Estados Membros é favorecida na medida em que a uniformização da aplicação do Direito do bloco é assegurada jurisdicionalmente, oferecendo, assim, segurança jurídica e estabilidade ao Direito referido, pois todos os órgãos jurisdicionais aplicarão o Direito da UE do mesmo modo, tal qual o entendimento expedido pelo Tribunal comunitário. Logo, quanto maior a integração entre os Estados, mais complexo será o sistema de solução de conflitos e maior será a necessidade de oferecer estabilidade jurídica aos destinatários do Direito.

\subsubsection{O impacto das decisões em sede prejudi- cial na formação dos princípios do Direito da UE}

Conforme mencionado anteriormente, a competência prejudicial do TJ/UE mantém-se essencialmente a mesma desde a ratificação do Tratado da CEE, em 1957, tendo seu exercício colaborado para que o Tribunal consolidasse, ao longo dos anos, os princípios e premissas do ordenamento jurídico da União por meio de sua jurisprudência, em especial o reconhecimento da supranacionalidade, o primado sobre o direito nacional, o efeito direto e a aplicabilidade imediata das normas comunitárias.

Uma decisão paradigmática para o Direito da União refere-se àquela proferida no acórdão Van Gend \& Loos, ${ }^{26}$ de 5 de fevereiro de 1963 . O caso envolvia uma empresa holandesa que se insurgiu contra um ato do Estado holandês, por ser violador do Tratado da CEE. Explica-se: ao ratificarem tal Tratado, os Estados comprometeram-se a não criar novos direitos aduaneiros,

25 VIEIRA, Luciane Klein. Interpretação e aplicação uniforme do direito da integração: União Europeia, Comunidade Andina, Sistema da Integração Centro-Americana e MERCOSUL. Curitiba: Juruá, 2013. p. 38-40.

26 TRIBUNAL DE JUSTIÇA DA COMUNIDADE EUROPEIA. Acórdão Van GEND \& LOOS c/ Administração Fiscal neerlandesa (Assunto C-26/62). Julgado em 05/02/1063. Disponível em: $<$ http:/ / curia.europa.eu/juris/showPdf.jsf?text $=\&$ docid $=87120 \&$ pageIndex $=0 \&$ doclang $=$ PT $\&$ mode $=$ req $\&$ dir $=\& o c c=$ first $\&$ part $=1$ \&cid=105558 > . Acesso em: 21 abr. 2018. mas sim, eliminar as barreiras alfandegárias e não alfandegárias, com o objetivo de gradualmente estabelecer o mercado comum. Entretanto, a empresa de importação, ante a jurisdição nacional competente, questionou o fato da autoridade tributária estatal exigir-lhe direitos alfandegários mais gravosos do que aqueles que eram devidos à data de entrada em vigor do Tratado referido.

Naquele período transitório, de implementação do que seria mais tarde o mercado comum europeu, colocava-se em pauta a capacidade do pacto ratificado pelos Estados Membros de criar direitos aplicáveis imediatamente aos particulares, em especial o direito de poder exigir o seu fiel cumprimento. A jurisdição nacional holandesa entendeu que seria necessária a interpretação de disposições do Tratado da CEE para solucionar a questão, e, portanto, formulou uma questão prejudicial ao então denominado Tribunal de Justiça da Comunidade Europeia (TJ/CE), nos termos do art. 177 do Tratado da CEE.

No procedimento prejudicial, outros Estados Membros, como a Bélgica e a Alemanha, apresentaram intervenções por meio da faculdade prevista no Estatuto do TJ/CE, participando, ativamente, da discussão acerca do alcance das normas do bloco.

Em sua decisão, o TJ/CE valorou os objetivos que pautaram a criação do Tratado da CEE, de modo a não o limitar às regras estritas do Direito Internacional Público tradicional, fazendo com que as normas comunitárias surtissem efeito direto sobre os particulares, nacionais residentes ou domiciliados nos Estados Membros.

Assim, o objetivo do Tratado da CEE, que "consiste em instituir um mercado comum cujo funcionamento diz respeito diretamente aos nacionais da Comunidade, implica que esse Tratado seja mais do que um acordo meramente gerador de obrigações recíprocas entre os Estados contratantes" 27 . Dessa forma, o TJ/CE destacou o papel dos particulares no processo de integração, atribuindo-lhes direitos e deveres imediatos a partir das normas dos Tratados constitutivos.

Ainda, nesse acórdão, o TJ/CE deixou claro o tipo de integração que se buscava no bloco europeu, pautada

27 TRIBUNAL DE JUSTIÇA DA COMUNIDADE EUROPEIA. Acórdão Van GEND \& LOOS c/ Administracão Fiscal neerlandesa (Assunto C-26/62), p. 220. Julgado em 05/02/1963. Disponível em: <http://curia.europa.eu/juris/showPdf.jsf?text $=\&$ docid $=871$ 20\&pageIndex $=0 \&$ doclang $=$ PT $\&$ mode $=$ req $\&$ dir $=\& o c c=$ first $\&$ par $\mathrm{t}=1 \&$ cid $=105558>$. Acesso em: 21 abr. 2018. 
em bases supranacionais, o que exige um maior compromisso entre os Estados e, consequentemente, uma maior eficácia do sistema de solução de controvérsias. Em outras palavras, o TJ/CE esclareceu que "a Comunidade constitui uma nova ordem jurídica de direito internacional, a favor da qual os Estados limitaram, ainda que em domínios restritos, os seus direitos soberanos, e cujos sujeitos são não só os Estados-Membros, mas também os seus nacionais". ${ }^{28}$

Outro caso digno de nota é o denominado Costa c/ ENEL, ${ }^{29}$ cuja decisão prejudicial foi proferida em 15 de julho de 1964. Nele, o TJ/CE determinou que, para que haja segurança jurídica intra bloco, deve haver o primado do Direito comunitário sobre o direito interno dos Estados Membros.

O substrato fático desse caso envolvia o sr. Flamínio Costa, cidadão italiano que se insurgiu contra a nacionalização do setor elétrico intentada pelo governo italiano, em contrariedade ao disposto no Tratado da CEE. No pedido judicial, o particular referido questionou qual seria o ente credor de sua conta de eletricidade — se a companhia de eletricidade que fora nacionalizada ou o "Ente nazionale energia elettrica", órgão governamental que havia encampado tal empresa. Diante de tal questão, o TJ/CE estabeleceu que:

\begin{abstract}
Efetivamente, ao instituírem uma Comunidade de duração ilimitada, dotada de instituições próprias, de capacidade jurídica, de capacidade de representação internacional e, mais especialmente, de poderes reais resultantes de uma limitação de competências ou de uma transferência de atribuições dos Estados para a Comunidade, estes limitaram, ainda que em domínios restritos, os seus direitos soberanos e criaram, assim, um corpo de normas aplicável aos seus nacionais e a si próprios.
\end{abstract}

Esta integração, no direito de cada Estado-membro, de disposições provenientes de fonte comunitária e, mais geralmente, os termos e o espírito do Tratado têm por corolário a impossibilidade, para os Estados, de fazerem prevalecer, sobre uma ordem jurídica por eles aceite numa base de reciprocidade, uma medida unilateral posterior que não se lhe pode opor.

Com efeito, a eficácia do direito comunitário não pode variar de um Estado para outro em função de

28 BORCHARDT, Klaus-Dieter. $O A B C$ do direito da União Europeia. Luxemburgo: Serviço de Publicações da União Europeia, 2011. p. 32.

29 Sobre o caso, ver: LAUREANO, Abel. O efeito directo do direito da União Europeia: uma visão condensada do enquadramento duma preeminente criação jurisprudencial. Revista da Faculdade de Direito UFPR, n. 57, p. 113-143, 2013. legislação interna posterior, sem colocar em perigo a realização dos objetivos do Tratado [.....$^{30}$

Mais tarde, o TJ/CE consolidou os princípios do efeito direto e do primado do Direito da União no acórdão Simmenthal, proferido em 9 de março de 1978, a partir do qual se pode observar um resgate dos leading cases anteriormente mencionados. Nessa ocasião, o Tribunal viu-se incumbido de "determinar as consequências decorrentes [...] em caso de contradição entre uma norma de direito comunitário e uma disposição posterior de direito interno" ${ }^{\prime 31}$, no sentido de auferir se seria necessária alguma medida interna de revogação ou anulação da norma incompatível.

No caso concreto, a incompatibilidade girava ao redor do estabelecimento, pelo direito italiano, de medidas internas de controle sanitário, bem como taxas alfandegárias, na fronteira, para o ingresso da carne para consumo humano proveniente de outro Estado. A empresa Simmenthal importava carne da França para a Itália e se insurgiu contra o controle referido e a cobrança de taxas, por considerar que ambos se constituíam em obstáculos à livre circulação de mercadorias, prevista no Tratado constitutivo da CEE, como um dos pilares da união aduaneira.

Sobre o tema, o TJ/CE ressaltou a missão do juiz enquanto protetor dos direitos conferidos aos particulares pelo Direito comunitário, esclarecendo que as normas internas incompatíveis deveriam ser consideradas imediatamente inaplicáveis, para garantir os efeitos da norma comunitária de modo uniforme em todos os Estados Membros. ${ }^{32}$

30 TRIBUNAL DE JUSTIÇA DA COMUNIDADE EUROPEIA. Acórdão Flaminio Costa cl ENEL (Assunto C-6/64), p. 555. Julgado em 15/07/1964. Disponível em: <http://curia.europa.eu/ juris $/$ showPdf.jsf?text $=\&$ docid $=87399 \&$ pageIndex $=0 \&$ doclang $=P$ T\&mode $=1$ st $\&$ dir $=\&$ occ $=$ first $\&$ part $=1 \&$ cid $=220375>$. Acesso em: 21 abr. 2018.

31 TRIBUNAL DE JUSTIÇA DA COMUNIDADE EUROPEIA. Acórdão Administração das Finanças do Estado c/ Sociedade Anónima Simmenthal (Assunto 106/77), p. 246. Julgado em 09/03/1978. Disponível em: <http://curia.europa.eu/juris/showPdf.jsf?text $=\&$ docid $=89693 \&$ pageIndex $=0 \&$ doclang $=$ PT \&mode $=1$ st $\&$ dir $=\& o c c$ $=$ first\&part=1\&cid=234005>. Acesso em: 21 abr. 2018.

32 Em 2016, foi decidido, em sede prejudicial, o caso "Puligienica Facility Esco SpA (PFE) c/ Airgest SpA", que se originou de uma disputa acerca da adjudicação de um contrato de exploração de serviços de limpeza e manutenção de um aeroporto civil na Itália. A jurisdição nacional questionou o TJ/UE acerca da interpretação de normas constantes na Diretiva $n^{\circ} 89 / 665$, que já havia sido objeto de análise no acórdão Fastweb (C-100/12). Nesta ocasião, o TJ/ UE se pronunciou no sentido de recordar que o acórdão proferido 
Já no acórdão Cassis de Dijon, datado de 20 de fevereiro de 1979, o TJ/CE deparou-se com a questão das medidas de efeito equivalente às restrições quantitativas impostas à importação de mercadorias entre os Estados Membros, que surgiu da restrição à comercialização, na Alemanha, do licor "cassis de Dijon", produzido na França.

Nessa decisão, o TJ/CE adverte que os obstáculos à circulação intracomunitária decorrentes da disparidade entre legislações nacionais somente deveriam ser tolerados na medida em que fossem estritamente necessários para proteger a saúde pública ou a defesa dos consumidores, por exemplo ${ }^{33}$.

Por outro lado, no caso Francovich e Bonifaci c/ Itália, ${ }^{34}$ decidido em 1991, o Tribunal comunitário deparou-se com a questão da responsabilidade internacional do Estado Membro face ao particular, oriunda do descumprimento da transposição de Diretiva, no prazo de 2 anos, conforme determinado no Tratado constitutivo. Sobre o tema, o TJ/CE se pronunciou no seguinte sentido:

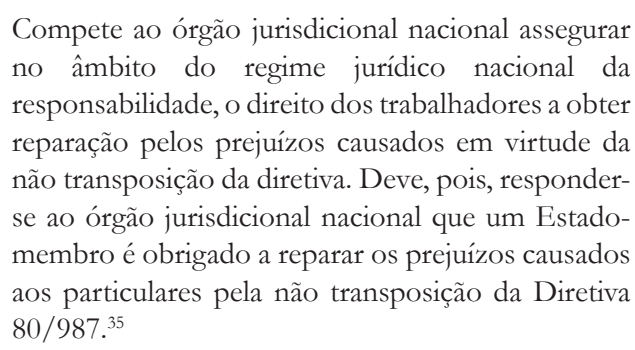

vincula o juiz nacional quando à interpretação ou à validade dos atos das instituições da União em causa, para a solução do litígio no processo principal. Ademais, "o efeito útil do artigo 267 do TFUE seria diminuído se o juiz nacional estivesse impedido de dar, imediatamente, ao direito da União uma aplicação conforme com a decisão ou com a jurisprudência do Tribunal de Justiça (v., neste sentido, acórdão Simmenthal, 106/77, EU:C:1978:49, n 20)". TRIBUNAL DE JUSTIÇA DA UNIÃO EUROPEIA. Acórdão Puligienica Facility Esco SpA (PFE) c/ Airgest SpA. Julgado em 05/04/2016. Disponível em: <http://eur-lex.europa.eu/legal-content/PT/TXT/ PDF/?uri=CELEX:62013CJ0689>. Acesso em: 26 abr. 2018. p. 10. 33 TRIBUNAL DE JUSTIÇA DA COMUNIDADE EUROPEIA. Acórdão Rewve-Zentral AG c/ Bundesmonopolverwaltung Für Branntwein (Assunto 120/78), p. 332. Julgado em 20/02/1979. Disponível em: $<$ http://curia.europa.eu/juris/showPdf.jsf?text $=\&$ docid $=900$ $55 \&$ pageIndex $=0 \&$ doclang $=\mathrm{pt} \&$ mode $=1$ st $\& \operatorname{dir}=\& o c c=$ first $\&$ part $=1 \&$ cid $=227876>$. Acesso em: 21 abr. 2018.

34 Sobre o caso, ver: FONTOURA, Jorge. A construção jurisprudencial do direito comunitário europeu. Revista de Informação Legislativa, n. 140, p. 163-170, 1998.

35 TRIBUNAL DE JUSTIÇA DA COMUNIDADE EUROPEIA. Acórdão Andrea Francovich e Daniela Bonifaci c/ República Italiana (Assunto 6/90 e 9/90), p. I - 5416. Julgado em 19/11/1991. Disponível em: <http:/ / curia.europa.eu/juris/showPdf.jsf?text $=\&$ docid $=97$ 140\&pageIndex $=0 \&$ doclang $=$ PT\& mode $=1$ st $\&$ dir $=\& o c c=$ first\&par
Dessa feita, por meio da análise das decisões paradigmáticas trazidas à colação, é possível reafirmar a relação intrínseca entre o sistema de solução de controvérsias da UE, o impacto produzido pelas decisões operadas em seu âmago na construção do Direito do bloco $^{36}$ e o desenvolvimento econômico do respectivo processo de integração, no sentido de que, quanto mais coesa, densa e uniforme são as respostas oferecidas pelo sistema referido, maior será o grau de integração econômica atingido.

\subsection{O sistema de solução de controvérsias do MERCOSUL}

O bloco do Cone Sul almejava, em seu princípio, objetivos que se revelariam impraticáveis em tão curto espaço de tempo, como previsto no Tratado de Assunção. ${ }^{37}$ Relativamente ao sistema de solução de controvérsias, este é voltado para a negociação, mediação e arbitragem entre os Estados Partes, inexistindo um tribunal com jurisdição obrigatória ou acessível aos particulares.

Como já visto, no MERCOSUL, inexiste uma estrutura supranacional, uma vez que os Estados Partes conservam intactas suas soberanias ao relacionarem-se uns com os outros. Dessa forma, a ausência de tal qualidade no sistema de solução de controvérsias é prejudicial a um esquema de integração mais profundo ou

$\mathrm{t}=1 \&$ cid=232164> . Acesso em: 21 abr. 2018.

36 O último leading case trazido à colação (Francovich e Bonifaci) igualmente vem sendo reiterado nas decisões posteriores do TJ/ UE. Nesse sentido, veja-se o caso "TDC A/S c/ Teleklagenaevnet", de 2016, no qual o juízo nacional indaga ao TJ/UE acerca da possibilidade de uma Diretiva produzir efeitos diretos. Em sua resposta, o TJ/UE fez remissão à sua jurisprudência, assinalando que “em todos os casos em que, atento ao seu conteúdo, disposições de uma diretiva sejam incondicionais e suficientemente precisas, os particulares têm o direito de as invocar nos tribunais nacionais contra o Estado, seja quando este não tenha transposto dentro do prazo a diretiva para o direito nacional, seja quando tenha feito uma transposição incorreta desta (acórdãos de 24 de janeiro de 2012, Dominguez, C-282/10, EU:C:2012:33, nº 33 e jurisprudência referida, e de 6 de outubro de 2015, T-Mobile Czech Republic e Vodafone Czech Republic, C-508/14, EU:C:2015:657, no 52 e jurisprudência referida)". TRIBUNAL DE JUSTIÇA DA UNIÃO EUROPEIA. Acórdão TDC A/S c/ Teleklagenaevnet. Julgado em 21/12/2016. Disponível em: <http://eur-lex.europa.eu/legal-content/PT/TXT/ PDF/?uri=CELEX:62015CJ0327>. Acesso em: 26 abr. 2018. p. 15 37 BARRAL, Welber. O Protocolo de Olivos e o MERCOSUL. 2010. Disponível em: <https://periodicos.ufsc.br/index.php/sequencia/ article/view/15336>. Acesso em: 20 out. 2017. 
mais denso. ${ }^{38}$

O Protocolo de Brasília, firmado em 1991, previsto para vigorar transitoriamente, instituiu um procedimento perante Tribunais Arbitrais ad hoc. Em 2002, o Protocolo de Olivos, que derrogou o Protocolo de Brasília, manteve em parte a sistemática adotada, restrita à resolução de conflitos entre os Estados Partes, mas introduziu uma mudança significativa. Por meio desse Protocolo, instituiu-se o Tribunal Permanente de Revisão - TPR, também de natureza arbitral, competente para conhecer controvérsias em grau de Recurso de Revisão ${ }^{39}$ ou em única instância, através da competência per saltum.

Com a criação do tribunal referido, parte da doutrina passou a entender que, durante o estágio de integração atual do MERCOSUL (que ainda não é um mercado comum), tal estrutura arbitral é, na verdade, benéfica ao desenvolvimento do bloco, por resguardar as vontades políticas dos Estados Partes. ${ }^{40}$ Dessa forma, o TPR representa um avanço na busca da harmonização da aplicação do Direito do MERCOSUL, uma vez que lhe foi atribuída a competência de dar a última palavra a respeito da interpretação deste. ${ }^{41}$

\subsubsection{O Tribunal Permanente de Revisão e as opiniões consultivas}

A criação do TPR e a competência não contenciosa atribuída a esse órgão para emitir opiniões consultivas ${ }^{42}$, solicitadas por distintos atores, ${ }^{43}$ são passos em direção

38 VIEIRA, Luciane Klein. Interpretação e aplicação uniforme do direito da integração: União Europeia, Comunidade Andina, Sistema da Integração Centro-Americana e MERCOSUL. Curitiba: Juruá, 2013. p. 119.

39 BARRAL, Welber. O Protocolo de Olivos e o MERCOSUL. 2010. Disponível em: <https://periodicos.ufsc.br/index.php/sequencia/ article/view/15336>. Acesso em: 20 out. 2017.

40 GOMES, Eduardo Biacchi. Blocos econômicos: solução de controvérsias. 3. ed. Curitiba: Juruá, 2010. p. 216.

41 VIEIRA, Luciane Klein. Interpretação e aplicação uniforme do direito da integração: União Europeia, Comunidade Andina, Sistema da Integração Centro-Americana e MERCOSUL. Curitiba: Juruá, 2013. p. 118-119.

42 As opiniões consultivas possibilitam que o juiz nacional solucione dúvidas acerca da normativa do MERCOSUL, visando a sua aplicabilidade no caso concreto. Nesse sentido, ver: FEIJÓ, Camilla de Freitas. $\mathrm{O}$ atual sistema de solução de controvérsias do MERCOSUL: rumo à consolidação de um tribunal regional. Revista de Direito Internacional UNICEUB, v. 9, n. 1, p. 72, 2012.

43 Aqui, é importante destacar que têm legitimidade ativa para solicitar opinião consultiva ao TPR os seguintes atores: a) os Estados Partes, atuando em conjunto; b) os órgãos com capacidade de- à uma maior integração entre os Estados do Cone Sul. ${ }^{44}$

Nesse sentido, a harmonização da interpretação e da aplicação das normas do MERCOSUL é, de certa forma, favorecida pela criação do TPR, instituição de caráter permanente. Entretanto, o texto normativo do Protocolo de Olivos não aborda a questão dos efeitos de tais decisões consultivas, ${ }^{45}$ o que minimiza sua eficiência no desempenho de sua missão harmonizadora, já que o órgão consultante não tem a obrigatoriedade de adotar a interpretação expedida pelo TPR.

Não obstante isso, as opiniões consultivas têm por objetivo promover maior harmonia e efetividade em relação à interpretação e aplicação do conjunto normativo do bloco, à semelhança da questão prejudicial da UE, que permitiu erigir os princípios basilares, que dão sustento à integração europeia. Porém, como a própria denominação indica, a solicitação da opinião consultiva não é obrigatória às jurisdições nacionais, e a resposta emitida pelo TPR tampouco vincula os juízes e tribunais dos Estados Partes, conforme o art. 11 da Decisão $\mathrm{CMC} \mathrm{n}^{\circ} 37 / 2003$ (norma regulamentadora do mecanismo processual).

O acórdão proferido pelo TPR em sede de opinião consultiva, por não ser vinculante, acaba por não conseguir cumprir com a missão a qual se destina. Essas características, que prejudicam a efetividade das opiniões consultivas, se relacionam, intrinsecamente, com a intergovernamentalidade existente na organização referida. Nesses termos, resgatamos o entendimento da doutrina, segundo o qual:

No sistema da intergovernabilidade MERCOSUL, o mecanismo de cooperação utilizado é o das opiniões consultivas que, a exemplo do modelo supranacional do reenvio prejudicial, é aplicado

cisória, a saber, o CMC, GMC e a Comissão de Comércio do MERCOSUL (CCM); c) os Tribunais Superiores dos Estados Partes; e d) o Parlamento do MERCOSUL. No que nos interessa, com relação à legitimidade ativa do Poder Judiciário, podem oferecer a consulta interpretativa ao TPR os seguintes órgãos: a) pela Argentina, a Corte Suprema de Justicia de la Nación (CSJN); b) pelo Brasil, o Supremo Tribunal Federal (STF); c) pelo Paraguai, a Corte Suprema de Justicia (CSJ); d) pelo Uruguai, a Suprema Corte de Justicia (SCJ) e o Tribunal del Contencioso Administrativo (TCA). A Venezuela ainda não indicou o órgão competente para o pedido de opiniões consultivas. 44 VIEIRA, Luciane Klein. Interpretação e aplicação uniforme do direito da integração: União Europeia, Comunidade Andina, Sistema da Integração Centro-Americana e MERCOSUL. Curitiba: Juruá, 2013. p. 118-119.

45 BARRAL, Welber. O Protocolo de Olivos e o MERCOSUL. 2010, p. 150. Disponível em: <https://periodicos.ufsc.br/index.php/sequencia/article/view/15336>. Acesso em: 20 out. 2017. 
quando as partes ou o próprio juiz nacional da causa possuem dúvidas quanto à aplicação e à interpretação de uma norma do bloco, no caso em concreto. Todavia, existem determinadas diferenças entre ambas:

a) A decisão da opinião consultiva não é vinculante, isto é, não obriga ao juiz nacional.

b) $\mathrm{Na}$ sistemática do Protocolo de Olivos, os particulares não podem, diretamente, suscitar a dúvida, a qual deve tramitar pelos Tribunais Superiores dos Estados e;

c) A instância jurisdicional nacional não é obrigada a aceitar o pedido de opinião consultiva ${ }^{46}$.

A intergovernamentalidade do MERCOSUL se revela como característica estruturante de seu sistema de solução de controvérsias, consideradas as limitações impostas pela inexistência de vinculação e obrigatoriedade de adoção da decisão do TPR em sede de opinião consultiva, a impossibilidade de acesso direto ${ }^{47}$ pelos particulares afetados pelo Direito da Integração e a reserva do rol de legitimados à solicitação de opinião consultiva — falando-se em Poder Judiciário — a um âmbito consideravelmente mais restrito daquele da questão prejudicial europeia, dentre outros obstáculos. Dessa forma, e levando em conta a etapa atual de integração econômica do MERCOSUL, que revela um menor compromisso entre os Estados, verifica-se que o sistema de solução de conflitos adotado pelo bloco é menos complexo que o europeu, na mesma proporção em que é menos eficiente, pelos motivos já relacionados.

46 GOMES, Eduardo Biacchi. Integração econômica no MERCOSUL: opiniões consultivas e a democratização no acesso ao Tribunal Permanente de Revisão. Revista de Direito Internacional UNICEUB, v. 10, n. 1, p. 132, 2013.

47 Há autores que defendem existir acesso direito do particular ao TPR. Nesse sentido, ver: GOMES, Eduardo Biacchi. La democratización del acceso al Tribunal Permanente de Revisión del MERCOSUR a través de las opiniones consultivas. Revista da Secretaria do Tribunal Permanente de Revisão, Assunção, n. 4, p. 49-63, ago. 2014. Entretanto, apesar do alargamento da legitimidade ativa para solicitação de opiniões consultivas, trazido pela normatização procedimental interna (no caso brasileiro, pela Emenda Regimental no 48 de 2012, do STF), o particular permanece com o acesso restrito ao sistema de solução de conflitos do MERCOSUL, voltado essencialmente para os Estados Partes.

\section{A UNIFORMIDADE CONFERIDA AO DIREITO DA INTEGRAÇÃO À LUZ DOS SISTEMAS DE SOLUÇÃO DE CONTROVÉRSIAS}

Segundo esclarece a doutrina, um dos elementos que indica o avanço de um processo de integração é justamente o seu sistema de solução de controvérsias, na medida em que este representa uma garantia dos direitos conferidos aos particulares abrangidos pela integração regional. ${ }^{48}$

A UE, que já conta com várias décadas de desenvolvimento, segue sendo o paradigma para o estudo jurídico dos processos de integração regionais, mesmo após momentos de turbulência (a exemplo da recente deflagração do processo de retirada do Reino Unido, apelidado pela imprensa internacional como Brexit).

Desde a gênese do bloco europeu, é notável o protagonismo desempenhado pelo então TJ/CE, hoje TJ/ UE, no sentido de interpretar, consolidar, harmonizar e, até mesmo, inovar no arcabouço jurídico do Direito da União. Princípios basilares daquele bloco tiveram origem em sua jurisprudência, a exemplo do efeito direto das normas europeias (acórdão Van Gend \& Loos, de 1963) e da primazia do Direito da União sobre o direito interno dos Estados Membros (acórdão Costa/ENEL, de 1964), ${ }^{49}$ como já referido. Nesse sentido,

Podemos observar uma acentuada participação do TJ/UE no fortalecimento da integração daquele bloco. [...] O impacto de sua jurisprudência [...] não deixa dúvida de que essa participação significa mais do que a mera aplicação da legislação em vigor [...]. Para nós, resta claro que o TJ/UE tem dado contribuição importante para o processo de integração regional europeu, mediante sua produção jurisprudencial e a formulação e solidificação de princípios, que, em alguns casos, influenciaram a criação ou a melhoria da legislação em vigor. ${ }^{50}$

A seu turno, a integração regional, no MERCOSUL,

48 PEROTTI, Alejandro Daniel. Tribunal Permanente de Revisión y Estado de Derecho en el MERCOSUR. Buenos Aires: Marcial Pons de Argentina, 2008. p. 14.

49 Em processos de integração como a UE, os leading cases decididos pelos Tribunais Regionais se deram justamente no marco das questões prejudiciais solicitadas por juízes nacionais. PEROTTI, Alejandro Daniel. Tribunal Permanente de Revisión y Estado de Derecho en el MERCOSUR. Buenos Aires: Marcial Pons de Argentina, 2008. p. 67-68.

50 CORREIA, Emanuella Chagas Jaguar. Efeito vinculante do reenvio prejudicial na União Europeia: um caminho para desenvolver o direito comunitário. Revista da Secretaria do Tribunal Permanente de Revisão, Assunção, n. 4, p. 70, ago. 2014. 
possui premissas históricas, políticas e socioeconômicas muito diferentes das europeias, de maneira que é impossível transplantar as soluções do bloco europeu para a realidade específica referida, dada sua fragilidade institucional e objetivos econômicos. Dessa forma,

Não apenas o sistema de solução de controvérsias,
mas a ordem jurídica como um todo recebe
considerações. A fragilidade institucional e
jurídica do MERCOSUL é incontestável. Seguem
existentes os mesmos problemas fundamentais: a
provisoriedade de parte dos instrumentos vigentes,
a ausência de uma instituição uniformizadora das
decisões, que busque evitar soluções diferenciadas
para situações aproximadas, e o não-estabelecimento
de mecanismos pelos quais os particulares possam
buscar, diretamente, a solução de seus problemas. ${ }^{51}$

A fragilidade descrita se evidencia, também, pelo decurso de tempo sem o exercício da cooperação entre as jurisdições nacionais e a regional. Desde a instalação do TPR até a presente data, aproximadamente 13 anos mais tarde, foram emitidas somente 3 opiniões consultivas. Ademais, os próprios árbitros do TPR lamentam a ausência de obrigatoriedade e vinculação conferidas ao mecanismo pela regulamentação do $\mathrm{CMC}^{52}$. Do mesmo modo, foram poucos os laudos arbitrais emitidos, sendo que o último deles se deu a conhecer no ano de 2012, e tratou da situação da suspensão do Paraguai da par-

51 JAEGER JUNIOR, Augusto. Metodologia jurídica europeia e mercosulista: considerações fundamentais. Revista da Secretaria do Tribunal Permanente de Revisão, Assunção, n. 3, p. 139, mar. 2014.

52 A primeira opinião consultiva do MERCOSUL foi prolatada em 03/04/2007, a pedido da Magistrada de Primeira Instância Civil e Comercial de Assunção, Paraguai, e versava sobre a aplicação do Protocolo de Buenos Aires sobre Jurisdição Internacional em Matéria Contratual, em caso envolvendo uma empresa argentina e outra paraguaia, que litigavam acerca do foro competente para dirimir suas controvérsias - se aquele determinado pela norma do MERCOSUL ou o indicado pela norma interna paraguaia. $\mathrm{O}$ árbitro Wilfrido Fernández de Brix, encarregado da relatoria do parecer consultivo, lamenta a ausência de vinculação das jurisdições nacionais à interpretação fixada pelo TPR ao discorrer acerca do conceito, natureza e objetivo das opiniões consultivas, ao dizer: "por outro lado, no nosso regime atual, lamentavelmente a mal chamada opinião consultiva não é obrigatória nas circunstâncias precedentemente esboçadas, nem muito menos vinculante para o juiz nacional consultante. Em primeiro termo, é característica de todo tribunal sua imperatividade, mas, muito mais que isso, com um sistema não obrigatório, nem vinculante ao magistrado nacional, se desnaturaliza por completo o conceito, a natureza e o objetivo do que deve ser um correto sistema de interpretação prejudicial. Isso confronta principalmente com o objetivo da consulta do juiz nacional no âmbito de um processo de integração que é lograr a interpretação da norma comunitária de maneira uniforme em todo o território integrado [...]”. MERCOSUL. Tribunal Permanente de Revisão. Opinião consultiva $n^{0} 01$ de 2007. Disponível em: <http://tprmercosur.org/pt/docum/opin/ OpinCon_01_2007_pt.pdf>. Acesso em: 12 mai. 2017. ticipação nos órgãos decisórios do MERCOSUL e do respectivo ingresso da Venezuela ao bloco.

Devido ao longo desenvolvimento da UE, sobretudo com relação à questão prejudicial, esse bloco econômico serve como referência e, porque não, fonte de inspiração à consolidação do direito da integração do MERCOSUL, observadas as diferenças de contexto socioeconômico e político de cada realidade. Tal inspiração pode ser, inclusive, reconhecida na fundamentação da primeira opinião consultiva proferida pelo TPR ${ }^{53}$.

Dessa forma, passa-se a explorar de que maneira poderia ocorrer o fortalecimento da atuação do TPR para a consolidação e o aprofundamento da integração, no MERCOSUL, por meio da análise comparativa com o TJ/UE — sem olvidar que um simples "transplante" de soluções consagradas no contexto europeu não é somente impossível, como também indesejável à realidade sul-americana.

\subsection{Independência do TJ/UE e questão prejudicial}

Para desempenhar sua função de modo imparcial, o TJ/UE conta com garantias para assegurar sua independência, como o caráter supranacional de sua jurisdição e a delimitação de suas competências pelo Direito europeu originário.

Além disso, o TJ/UE, enquanto instituição, dispõe de recursos próprios, oriundos de dotação orçamentária constante da Seção 4 do Orçamento Geral da UE, destinados a custear sua atividade. Ademais, seus juízes são escolhidos entre personalidades que ofereçam todas as garantias de independência e reúnam as condições estabelecidas nos arts. $253^{\circ}$ e $254^{\circ}$ do TFUE.

Nesse cenário, a questão prejudicial constitui o mecanismo apto para promover a uniformidade da inter-

53 Ainda na redação da $\mathrm{OC} \mathrm{n}^{\circ}$ 01/2007, referida na nota anterior, o árbitro, ao tecer argumentação favorável à uma hierarquia diferenciada das normas do bloco em face dos ordenamentos nacionais dos Estados Partes, menciona o seguinte: "recordemos a origem pretoriana da prevalência do direito comunitário na União Europeia: 'a origem do princípio de primazia conforme o mesmo tribunal comunitário, não deve buscar-se em previsões ou reconhecimentos do direito nacional dos Estados que participam do processo da integração, senão na própria natureza do direito da comunidade"'. MERCOSUL. Tribunal Permanente de Revisão. Opinião consultiva $n^{\circ}$ 01 de 2007. p. 08. Disponível em: <http://tprmercosur.org/pt/docum/opin/OpinCon_01_2007_pt.pdf>. Acesso em: 12 maio 2017. 
pretação do Direito da União, uma vez que vincula a jurisdição nacional que formulou a questão, objeto da consulta, e todas as demais jurisdições abarcadas pelo território integrado. $\mathrm{Na}$ medida em que a jurisprudência do próprio TJ/UE admite o afastamento da obrigatoriedade da questão prejudicial à última instância do Poder Judiciário nacional, em caso de já ter decidido questionamento anterior semelhante, conclui-se que o efeito vinculante do acórdão do TJ/UE, em sede prejudicial, extrapola o âmbito subjetivo do contexto em que foi solicitado. Sendo assim, conforme Campos e Campos:

o TJUE admite, em contrapartida, que a autoridade de seu acórdão pode ultrapassar o quadro do caso concreto, na medida em que dispensa os tribunais supremos dos Estados-Membros da obrigação de reenvio que lhes impõe o art. $267^{\circ}$ [do TFUE] sempre que a questão de interpretação perante eles suscitada tenha já sido julgada por acórdão anterior do TJUE. ${ }^{54}$

No que diz respeito à autoridade ou obrigatoriedade do acórdão interpretativo do TJ/UE, sua cogência não advém de disposição normativa expressamente positivada, sendo, ao contrário, oriunda da interpretação sistêmica do Direito da União, construída através da própria jurisprudência da Corte referida. Sobre o tema, a doutrina, referindo-se ao acórdão Milch, Fett-und Eierkontor, decidido pelo TJ/CE em 1969, destaca que:

Lo mismo ocurre en la CE [Comunidade Europeia,
hoje União Europeia], donde el Tribunal de Justicia
ha interpretado que del espíritu y el sistema del
Tratado surge que la sentencia emitida en el marco de
una cuestión prejudicial, debe ser obligatoriamente
acatada por el órgano jurisdiccional nacional
requirente.

Partindo ainda de outra premissa: o TJ/UE é a instituição garantidora do respeito do Direito na interpretação e aplicação dos Tratados, uma vez que lhe foi atribuída a competência precípua de ditar a última palavra relativamente ao Direito da União ${ }^{56}$. Portanto, é patente a vinculação da jurisdição nacional à resposta formulada pelo TJ/UE em sede de questão prejudicial ${ }^{57}$. Inclusive,

54 CAMPOS, João Mota de; CAMPOS, João Luiz Mota de. Manual de direito europen: o sistema institucional, a ordem jurídica e o ordenamento económico da União Europeia. 6. ed. Coimbra: Wolters Kluwer, 2010. p. 437.

55 PEROT'TI, Alejandro Daniel. Tribunal Permanente de Revisión y estado de derecho en el MERCOSUR. Buenos Aires: Marcial Pons de Argentina, 2008. p. 80-81.

56 De acordo com o art. $19^{\circ}$ do TUE.

57 Faz-se a ressalva de que inexiste relação hierárquica entre o julgador nacional e o TJ/UE, uma vez que na verdade existe o reparto de competências: enquanto ao juiz nacional cabe o deslinde da situ- o não acatamento da interpretação ditada pelo tribunal referido, pelo juiz nacional, pode implicar sanções ao Estado de origem deste, podendo chegar, inclusive, à expulsão do país da organização internacional, por descumprimento do Direito da União. ${ }^{58}$

\subsection{O TPR e a competência consultiva: a busca pela uniformidade na interpretação do Direito do MERCOSUL e as suas limitações}

O TPR, de natureza intergovernamental e arbitral, integra o ainda provisório sistema de solução de controvérsias do MERCOSUL. Dentre suas fragilidades, diferenciam-se as estruturais daquelas relacionadas às suas competências. Como exemplo, destaca-se o fato de que o Tribunal referido não possui autonomia em termos orçamentários:

El TPR no tiene un presupuesto asignado para atender a los gastos del órgano propiamente considerado, sino sólo para afrontar los casos de controversias y opiniones consultivas. [...] Se aprobó un pequeño presupuesto para hacer frente a los gastos más urgentes de funcionamiento del TPR, así como al sueldo del Secretario. La falta de un presupuesto constituye una debilidad importante del TPR. ${ }^{59}$

Em relação à fragilidade institucional, é necessário mencionar que certos dispositivos do próprio Protocolo de Olivos, bem como de sua regulamentação (principalmente a Decisão CMC no 37/2003) atuam restritivamente sobre as competências do TPR, tanto na contenciosa como na consultiva.

Previstas de forma inédita e sucinta no art. $3^{\circ}$ do Protocolo de Olivos, o objetivo das opiniões consultivas é a busca pela uniformidade e efetividade na interpretação do Direito do MERCOSUL. Tudo isto de maneira semelhante à questão prejudicial europeia e em

ação concreta, ao TJ/UE cabe a interpretação e a apreciação da validade das normas do Direito da União pertinentes à solução do caso (que permanece sob a competência exclusiva do juiz solicitante da questão prejudicial).

58 Sobre o tema, ver: VIEIRA, Luciane Klein. Interpretação e aplicaşão uniforme do direito da integração: União Europeia, Comunidade Andina, Sistema da Integração Centro-Americana e MERCOSUL. Curitiba: Juruá, 2013. p. 67.

59 PEROTTI, Alejandro Daniel. Elementos básicos para la constitución de un Tribunal de Justicia del MERCOSUR. La reforma institucional del MERCOSUR, 2008. Disponível em: <http://www.stf.jus.br/ arquivo/cms/sextoEncontroConteudoTextual/anexo/Texto_dos_ Exposiotres/Elementos_basicos_para_la_constitucion_Alejandro_Perotti.pdf>. Acesso em: 25 fev. 2018. 
conformidade com os princípios e anseios veiculados pelo Tratado de Assunção, marco jurídico fundante do bloco referido.

Contudo, as opiniões consultivas sofreram drástica restrição ao serem regulamentadas pelo CMC. A legitimação ativa para a solicitação ficou restrita a um pequeno rol de sujeitos, a saber: os Estados Partes, atuando em conjunto; os órgãos decisórios do MERCOSUL (CMC, o GMC e a CCM); os Tribunais Supremos dos Estados Partes, dotados de jurisdição nacional; e o Parlamento do MERCOSUL. Ainda que, em termos de legitimados ativos para a solicitação da consulta, o rol de atores habilitados seja maior do que o previsto na UE, com relação à participação do Poder Judiciário nacional — que é o que nos interessa — , esta se viu bastante limitada. Ou seja, enquanto no bloco europeu, qualquer juiz, de qualquer instância, pode formular uma consulta prejudicial diretamente ao TJ/UE, no MERCOSUL, o CMC limitou a faculdade para a formulação de consulta ao TPR aos tribunais superiores dos Estados Partes, o que não permite a atuação direta entre os juízes nacionais de primeira instância e o Tribunal da região.

Tendo em vista a cooperação jurídica esperada em um esquema de integração, pode-se afirmar que a regulamentação da opinião consultiva pelo CMC não favoreceu o diálogo entre as jurisdições nacionais e a do MERCOSUL. Isto porque impõe obstáculos ao acesso do juiz nacional de instâncias inferiores, que é, na verdade, o sujeito encarregado de aplicar as normas do bloco econômico ao cotidiano dos particulares por elas afetados.

Com relação à ausência de obrigatoriedade na formulação do pedido de opinião consultiva ao TPR e à não vinculação ao pronunciamento expedido, entende-se que a Decisão CMC no 37/2003 (art. 11) andou na contramão do aprofundamento da integração regional. Esse regime discrepa do europeu, de modo a prejudicar o alcance da uniformização da interpretação do Direito do MERCOSUL. Assim, segundo Perotti, em caso de verdadeiramente existir interesse em garantir a integração do bloco, a regulamentação restritiva das opiniões consultivas deve ser alterada, para possibilitar o cumprimento de sua finalidade. ${ }^{60}$

Dessa forma, entende-se que o CMC, ao exercer a

60 PEROTTI, Alejandro Daniel. Tribunal Permanente de Revisión y Estado de Derecho en el MERCOSUR. Buenos Aires: Marcial Pons de Argentina, 2008. p. 75-81. sua competência legislativa de regulamentação da opinião consultiva, agiu em contrariedade ao disposto pelo próprio preâmbulo do Tratado de Assunção, segundo o qual os Estados Partes "reafirmam sua vontade politica de estabelecer as bases para a união cada vez, mais estreita entre seus povos", pois a ausência de obrigatoriedade e de efeitos vinculantes em muito prejudica a tarefa de harmonizar a interpretação do Direito do MERCOSUL, conforme o entendimento da doutrina especializada e do próprio TPR. ${ }^{61}$

Em nota acerca da competência contenciosa do TPR, igualmente prevista no sistema de solução de controvérsias do MERCOSUL, o Protocolo de Olivos pretendeu mitigar a prática do forum shopping e da propositura de demandas em duplicidade pelos Estados Partes em mais de um foro ${ }^{62}$, já que, sob o sistema do Protocolo de Brasília, era possível levar uma mesma controvérsia tanto ao sistema do MERCOSUL como também a outro esquema multilateral do qual os litigantes participassem, de forma concomitante. Dessa forma, o Protocolo de Olivos, em seu art. $1^{\circ}$, limitou-se a impor aos Estados Partes a impossibilidade de reapresentar uma demanda, no âmbito do MERCOSUL, se ela já foi proposta em outro foro, e vice-versa, em virtude da denominada cláusula de opção de foro. Essa possibilidade de afastamento do sistema regional pode prejudicar a integração, como defende Gomes ${ }^{63}$.

Como se pode observar, as limitações impostas ao TPR são muitas. ${ }^{64}$ Elas podem ser tanto de caráter ins-

61 Conforme se depreende da já mencionada redação da OC $\mathrm{n}^{\circ}$ 01/2007, na qual os árbitros do TPR enunciam o enfraquecimento do potencial das opiniões consultivas para brindar uniformidade à interpretação do Direito do MERCOSUL, em face de não serem nem vinculantes, nem obrigatórias.

62 Segundo a doutrina, o incidente que originou esta disposição convencional foi o caso das medidas antidumping aplicadas pela Argentina ao Brasil, com relação à venda de frangos congelados. Ainda sob a égide do Protocolo de Brasília, o Brasil demandou a Argentina perante o sistema de solução de controvérsias do MERCOSUL. Porém, insatisfeito com o resultado prolatado pelo Tribunal Arbitral Ad Hoc, o Brasil então propôs a mesma controvérsia perante a Organização Mundial do Comércio (OMC). PEROTTI, Alejandro Daniel. Tribunal Permanente de Revisión y Estado de Derecho en el MERCOSUR. Buenos Aires: Marcial Pons de Argentina, 2008. p. 59-60.

63 GOMES, Eduardo Biacchi. Blocos econômicos: solução de controvérsias. 3. ed. Curitiba: Juruá, 2010. p. 164.

64 O sistema de solução de controvérsias do MERCOSUL detém ainda outras limitações, não abordadas aqui, como a escassez dos recursos humanos da Secretaria do TPR; a curta duração do mandato dos árbitros, que é de somente três anos; seu sistema remuneratório, dentre outros. PEROTTI, Alejandro Daniel. Tribunal Permanente de Revisión y estado de derecho en el MERCOSUR. Buenos Aires: Marcial 
titucional, prejudicando sua autonomia orgânica, como também de natureza jurídica, a exemplo da possibilidade de escolha de foro alheio ao processo de integração. A dependência orçamentária; a fraca ou incipiente cooperação judicial com as jurisdições internas dos Estados Partes, demonstrada pelo baixo número de opiniões consultivas solicitadas e ainda tantos outros fatores acabam por debilitar a função do TPR na consolidação da integração regional.

\subsubsection{A construção dos princípios do Direito da Integração, no MERCOSUL, a partir das decisões em sede consultiva}

Desde a sua regulamentação pela Decisão $\mathrm{CMC} \mathrm{n}^{\circ}$ 37/2003 até a presente data (abril de 2018), somente foram proferidas três opiniões consultivas pelo TPR.

A primeira opinião consultiva, emitida em $2007,{ }^{65}$ originou-se de uma questão formulada pela juíza María Angélica Calvo, de "Primera Instancia en lo Civil y Comercial del Primer Turno" da jurisdição de Assunção, no Paraguai. No caso concreto, a empresa paraguaia (Norte S/A Imp. Exp.) demandou, em Assunção, a empresa argentina (Laboratórios Northia), pedindo indenização por perdas e danos e lucros cessantes, em razão do descumprimento do contrato internacional de distribuição. A empresa argentina, por sua vez, apresentou exceção de incompetência, alegando a prevalência do Protocolo de Buenos Aires sobre Jurisdição Internacional em Matéria Contratual sobre a lei nacional paraguaia no 194/1993 e a necessidade de respeito à eleição de foro efetuada no contrato celebrado entre as partes, onde se optou pela jurisdição dos tribunais ordinários da Cidade Autônoma de Buenos Aires. Na defesa, a empresa paraguaia sustentou que era competente a jurisdição do Paraguai, em virtude do seu caráter irrenunciável e que resultaria aplicável, ademais, o Protocolo de Santa Maria sobre Relações de Consumo, ${ }^{66}$ por considerar que o contrato

Pons de Argentina, 2008. p. 31-66.

65 TRIBUNAL PERMANENTE DE REVISÃO DO MERCOSUL. "Norte S.A. Imp. Exp. c/ Laboratorios Northia Sociedad Antónima, Comercial, Industrial, Financiera, Inmobiliaria y Agropecuaria s/ Indemnización de Daños y Perjuicios y Lucro Cesante". (OC no 01/2007). Emitida em 03/04/2007. Disponível em: <http://www.tprmercosur.org/es/docum/opin/OpinCon_01_2007_es.pdf>. Acesso em: 22 abr. 2018.

66 Sobre a opinião consultiva referida, que contribuiu para a formação da qualificação de "consumidor", no MERCOSUL, posteriormente incorporada à Resolução no 34/2011, do GMC, sobre "Defesa do Consumidor - Conceitos Básicos", ver: VIEIRA, Luci- de distribuição era matéria de consumo.

Diante dos fatos narrados, o que se debateu na opinião consultiva foi a questão do conflito de fontes, para determinar qual delas seria aplicável (se a norma do MERCOSUL ou a nacional), uma vez que a norma a ser utilizada determinaria, por consequência, se o acordo de eleição de foro, celebrado entre as partes, era válido ou não e qual seria o juiz competente.

Não obstante, antes de adentrar na questão colocada, o TPR dedicou-se à análise da tarefa que lhe incumbia, e de sua importância institucional para o processo de integração do MERCOSUL, inclusive traçando um paralelo com mecanismos similares existentes em outros processos de integração, como nomeadamente, aqueles do Tribunal de Justiça da Comunidade Andina (TJ/CAN) e do próprio TJ/UE.

Por fim, apesar de mencionar como intrínsecos ao Direito da Integração os princípios da aplicação imediata, do efeito direto e da prevalência do direito do bloco sobre o direito interno, a maioria dos árbitros do TPR votou no sentido de que "as normas do MERCOSUL internalizadas prevalecem sobre as normas do direito interno dos Estados Partes. O Protocolo de Buenos Aires se aplica nos países que o internalizaram [...]." ${ }^{67}$ Dessa maneira, ao mencionar a necessidade de internalização das normas do MERCOSUL, e a não aplicação do Protocolo de Santa Maria, por não se tratar de uma relação internacional de consumo e pelo fato de este não estar vigente, o TPR reconheceu que os direitos e deveres contidos nestas não são, afinal, diretamente aplicáveis aos particulares, sujeitos da integração, por não se estar diante de um processo de integração com características supranacionais, mas sim ante um processo que depende, sobremaneira, das normas clássicas do Direito Internacional Público.

Como se pode observar, essa decisão se distancia daquela tomada pelo TJ/UE, nos casos Van Gend \& Loos e Simmenthal, o que demonstra, uma vez mais, a rela-

ane Klein. La hipervulnerabilidad del consumidor transfronterizo y la función material del derecho internacional privado. Buenos Aires: La Ley, 2017. p. 17-19.

67 TRIBUNAL PERMANENTE DE REVISÃO DO MERCOSUL. "Norte S.A. Imp. Exp. c/ Laboratorios Northia Sociedad Antónima, Comercial, Industrial, Financiera, Inmobiliaria y Agropecuaria s/ Indemnización de Daños y Perjuicios y Lucro Cesante" (OC no 01/2007), p. 36. Emitida em 03/04/2007. Disponível em: <http://www.tprmercosur.org/es/docum/opin/ OpinCon_01_2007_es.pdf>. Acesso em: 22 abr. 2018. 
ção intrínseca entre o grau de compromisso econômico assumido pelos Estados membros de um processo de integração, as características da supranacionalidade e intergovernamentalidade, e a consequente efetividade do seu sistema de solução de controvérsias.

A segunda opinião consultiva, datada de $2008^{68}$, surgiu a partir do caso das empresas uruguaias Sucesión $S c h$ neck S.A., Galisur S.A. e CESIM Ltda, que se insurgiram contra o Estado uruguaio pela cobrança de "taxas consulares" previstas em lei interna que violava o Tratado de Assunção, criador do MERCOSUL, no que tange à eliminação de barreiras alfandegárias para a livre circulação das mercadorias. Mais uma vez, o TPR afirmou a primazia do direito do MERCOSUL por sobre as disposições internas, desde que o tratado tenha sido devidamente ratificado e internalizado pelos Estados Partes.

Entretanto, é válido ressaltar que, nessa opinião consultiva, o TPR afirma que não lhe corresponde pronunciar-se a respeito da aplicabilidade de normas internas em contradição com a normativa do bloco, ficando tal julgamento a cargo do juiz nacional diante do caso concreto. Sobre o tema, é possível estabelecer um contraponto com a jurisprudência do TJ/UE, em especial com o acórdão Simmenthal, no qual o tribunal referido colocou como missão do juiz nacional proteger os direitos conferidos aos particulares pelo Direito comunitário, por meio da inaplicabilidade da norma interna que lhe contrarie.

Por fim, a terceira e última opinião consultiva emitida pelo TPR, em $2009^{69}$, teve sua gênese numa controvérsia semelhante àquela referida no pronunciamento anterior, envolvendo a mesma lei interna contrária à normativa do MERCOSUL, de modo que o Tribunal se pronunciou em igual sentido.

Apesar de nenhuma das três opiniões consultivas referidas ter partido do Poder Judiciário brasileiro, de qualquer modo, é interessante trazer à colação a Peti-

68 TRIBUNAL PERMANENTE DE REVISÃO DO MERCOSUL. "Sucesión Carlos Schnek y otros c/Ministerio de Economía y Finanzas y otros. Cobro de pesos" (OC n ${ }^{\circ}$ 01/2008). Emitida em 24/04/2009. Disponível em: <http://www.tprmercosur.org/ es/docum/opin/OpinCon_01_2008_es.pdf > . Acesso em: 22 abr. 2018.

69 TRIBUNAL PERMANENTE DE REVISÃO DO MERCOSUL. "Frigorífico Centenario S.A. c/ Ministerio de Economía y Finanzas y otros. Cobro de pesos. IUE: 2-43923/2007. Exhorto" (OC $n^{\circ}$ 01/2009). Emitida em 15/06/2009. Disponível em: <http:// www.tprmercosur.org/es/docum/opin/OpinCon_01_2009_ es.pdf>. Acesso em: 22 abr. 2018. ção $\mathrm{n}^{\circ} 4.383$, protocolada em 2008, pela Renault do Brasil S.A. perante o STF, solicitando a emissão de opinião consultiva pelo TPR. Tal pedido jamais chegou a ser enviado ao Tribunal referido, uma vez que, quando da regulamentação interna, quatro anos mais tarde, já não havia interesse por parte da solicitante na interpretação requerida. ${ }^{70}$ No caso específico, — único pedido de opinião consultiva solicitado no país — é de se destacar o problema do decurso do tempo entre o pedido de envio da consulta ao TPR, formulado em 13 de agosto de 2008 e a decisão do Ministro Joaquim Barbosa, no sentido de consultar a parte requerente da manutenção do interesse no envio desta, que se deu somente em 21 de outubro de 2013. Se o que se quer é efetividade processual, e ao mesmo tempo se necessita da interpretação do Direito para a solução do caso concreto, não há sentido, em um trâmite estritamente administrativo, aguardar 5 anos para a remessa do pedido ao TPR, o que deveria se dar quase que instantaneamente.

Ainda, é de se destacar que o STF modificou o seu Regimento Interno (RISTF) por meio da Emenda Regimental (ER) $n^{\circ} 48$, de $2012^{71}$, que viabilizou, procedimentalmente, a solicitação de opinião consultiva por qualquer juiz nacional, de ofício ou a requerimento das partes, sendo a decisão do STF de encaminhamento ao TPR de natureza administrativa e vinculada. ${ }^{72}$ Diferen-

70 Sobre o tema, ver: ARRUDA, Elisa. As opiniões consultivas do Tribunal Permanente de Revisão do MERCOSUL e o caso Renault do Brasil S.A. Revista Iberoamericana de Derecho Internacional y de la Integración, Buenos Aires, n. 7, Dic. 2017. Disponível em: < http://www. ijeditores.com.ar/pop.php?option $=$ articulo\&Hash $=\mathrm{e} 7 \mathrm{~d} 965040 \mathrm{a} 8 \mathrm{a} 5$ 8112249bafc497e21dc>. Acesso em: 25 fev. 2018.

71 A Decisão CMC no 02/2007 determina, a nível regional, que a solicitação de opiniões consultivas ao TPR deverá regulamentar-se por procedimento interno estabelecido por cada Tribunal Superior de Justiça dos Estados Partes. No Brasil, tal regulamentação foi disciplinada pelo STF mediante a ER n ${ }^{\circ} 48$, em 2012, que estabeleceu a tramitação nacional da solicitação até seu encaminhamento ao TPR. Ressalta-se que a competência para decidir sobre o encaminhamento ao TPR cabe ao plenário do STF, e o processo de colheita de votos poderá dar-se através de processo digital, ou, ainda, em sessão administrativa. O STF realiza juízo prévio de admissibilidade, de modo a auferir o preenchimento dos requisitos elencados nos arts. 354-H a 354-J do RISTF, a saber: apresentação por escrito; origem em processo em curso perante o Poder Judiciário brasileiro, mediante requerimento do juiz da causa ou de alguma das partes; questão relativa à vigência ou interpretação jurídica de norma do MERCOSUL, a ser precisamente indicada; exposição fática e do objeto da solicitação e, ainda, descrição das razões que motivaram o questionamento. VIEIRA, Luciane Klein; MARTINS FILHO, Marcos Simões. As opiniões consultivas do MERCOSUL solicitadas pelo Poder Judiciário brasileiro. Revista dos Tribunais, São Paulo, v. 931, p. 217-236, maio 2013.

72 VASCONCELOS, Raphael Carvalho; TAVARES, Sergio Maia. 
temente da regulamentação interna dos demais Estados do bloco, a brasileira permite, expressamente, a participação do juiz nacional na cooperação referida. ${ }^{73}$

Diante do reduzido número de opiniões consultivas proferido face ao lapso temporal desde sua inserção no ordenamento jurídico do MERCOSUL, aliado a todas as outras restrições e limitações já abordadas, é possível concluir que o papel desse mecanismo, para buscar a uniformidade e a efetividade em relação à interpretação do Direito do MERCOSUL, resta prejudicado, o que não se verifica com relação à atuação do TJ/UE na consolidação da integração regional daquele bloco.

\subsection{Possibilidades para o fortalecimento da função do TPR, inspiradas na experiência do TJ/ UE}

Como já fora mencionado, um simples "transplante" das soluções consagradas no contexto europeu não é possível ou desejável à realidade do MERCOSUL, uma vez que seu contexto é outro. Nesse sentido, a doutrina assinala que a supranacionalidade, que pauta o sistema de solução de controvérsias da UE, está distante da realidade do Cone Sul, na medida em que:

As noções vertidas no Direito da União ainda não
resultam transferíveis ao MERCOSUL, posto que
esse não é uma organização supranacional. Ele
carece de organismos comunitários com poderes
legislativos delegados, pelo que as normas que
emanam de seus órgãos carecem de eficácia direta
e devem ser incorporadas aos ordenamentos
jurídicos de cada Estado conforme os respectivos
mecanismos constitucionais vigentes. ${ }^{74}$

Entretanto, a partir da experiência europeia, que se

A competência consultiva do Tribunal Permanente de Revisão do MERCOSUL: legitimidade e objeto. Revista da Secretaria do Tribunal Permanente de Revisão, Assunção, v. 4, p. 117-134, ago. 2014.

73 Para detalhes sobre a regulamentação dispensada pelos demais Estados Partes, ver: VIEIRA, Luciane Klein. Interpretação e aplicação uniforme do direito da integração: União Europeia, Comunidade Andina, Sistema da Integração Centro-Americana e MERCOSUL. Curitiba: Juruá, 2013. p. 140-144. Tal como destaca a autora, o Uruguai foi o primeiro Estado Parte a regulamentar o procedimento do pedido de opinião consultiva, através da Acordada n ${ }^{\circ}$ 7.604, da Suprema Corte de Justicia, de agosto de 2007. Já a Argentina o fez através da Acordada ${ }^{\circ} 13$, da Suprema Corte de Justicia de la Nación, em junho de 2008. Por sua vez, o Paraguai disciplinou internamente a matéria, através da Acordada no 549, em novembro do mesmo ano. O Brasil, conforme já destacado, somente regulamentou a questão em 2012, através da ER n ${ }^{\circ} 48$ do STF.

74 JAEGER JUNIOR, Augusto. Metodologia jurídica europeia e mercosulista: considerações fundamentais. Revista da Secretaria do Tribunal Permanente de Revisão, Assunção, n. 3, p. 146, mar. 2014. desenvolve já há várias décadas, é possível considerar a implementação de mudanças pontuais ao sistema de solução de controvérsias do MERCOSUL, atualmente pautado pelo Protocolo de Olivos e sua respectiva regulamentação, conforme se sustenta a seguir.

O importante papel desempenhado pelo TJ/UE para a consolidação da integração europeia, que atua de maneira ativa na construção do Direito da União, somente se faz possível em virtude de sua autonomia institucional e robustez jurisdicional, manifestadas por meio da jurisdição obrigatória aos Estados Membros, os quais estão vinculados às decisões emitidas pelo TJ/ UE, tanto em sede contenciosa como em relação aos acórdãos interpretativos.

No que tange aos aspectos estruturais do TPR, entende-se necessário alcançar uma efetiva autonomia orçamentária, vinculada à instituição, o que está distante da situação atual ${ }^{75}$. Ao mesmo tempo, advoga-se pela transformação do TPR em órgão de existência verdadeiramente contínua, por meio da superação da mera disponibilidade permanente de seus árbitros.

No que se refere à competência do TPR em sede consultiva, o MERCOSUL em muito se beneficiaria da alteração da regulamentação das opiniões consultivas, em especial no que diz respeito à cooperação com as jurisdições internas de seus Estados Partes. Assim, defende-se que a normativa do MERCOSUL avance no sentido de eliminar a restrição da legitimidade ativa de modo a possibilitar aos juízes nacionais estabelecer um diálogo direto com o TPR, sem complicações burocrático-procedimentais. ${ }^{76}$

Ademais, sugere-se a revogação do já aludido art. 11 da Decisão CMC no 37/2003, de modo a tornar obrigatória a solicitação de opinião consultiva ao TPR,

75 Tal como destacado, "en el MERCOSUR existe - comparativamente - un pequeño fondo presupuestal para las controversias, pero no ocurre lo mismo en cuanto al Tribunal, como órgano propiamente dicho.” PEROTTI, Alejandro Daniel. Tribunal Permanente de Revisión y estado de derecho en el MERCOSUR. Buenos Aires: Marcial Pons de Argentina, 2008. p. 35.

76 No Uruguai, Argentina, Paraguai e Brasil, a legitimidade foi estendida aos demais órgãos jurisdicionais inferiores, de maneira que podem agir de ofício ou a requerimento das partes, devendo, entretanto, apresentar a solicitação primeiramente à cúpula de seu sistema judiciário - o que, na prática, consiste em obstáculo burocrático à cooperação entre jurisdições regional e nacionais. VASCONCELOS, Raphael Carvalho; TAVARES, Sergio Maia. A competência consultiva do Tribunal Permanente de Revisão do MERCOSUL: legitimidade e objeto. Revista da Secretaria do Tribunal Permanente de Revisão, Assunção, v. 4, p. 121, ago. 2014. 
quando se tratar de instância judiciária nacional, de cujas decisões não caiba recurso, bem como reconhecer a autoridade $^{77}$ do pronunciamento interpretativo do TPR, de modo a privilegiar a segurança jurídica e garantir a uniformização da interpretação e aplicação do Direito pelos ordenamentos jurídicos dos Estados Partes. Em outras palavras,

como se puede vislumbrar, el sistema adoptado en el MERCOSUR - donde la respuesta del TPR en materia de OC carece de efecto obligatorio - no garantiza de forma efectiva la aplicación e interpretación uniforme del Derecho del bloque, ya que la hermenéutica a la que arribe el Tribunal podrá ser aplicada en un Estado Parte y no en otro. ${ }^{78}$

A partir da adoção das mudanças propostas, vislumbra-se a possibilidade de um avanço paulatino na integração do bloco do Cone Sul, no que diz respeito a seu sistema de solução de controvérsias, mantendo-se por hora sua provisoriedade e natureza arbitral, porém agregando-lhe elementos de maior pujança, uma vez que a implementação de uma jurisdição supranacional, de natureza judicial e definitiva, nos parece improvável em um futuro próximo, dadas as vicissitudes de âmbito socioeconômico e político que circundam o desenvolvimento do MERCOSUL.

\section{Coniderações finais}

Como se pode observar, de fato, existe uma relação de interdependência entre o aprofundamento da integração regional de determinado bloco econômico e o desenvolvimento e eficiência de seu sistema de solução

77 Nesse sentido, adverte a mais autorizada doutrina: “en el caso de la justicia del MERCOSUR, se apunta a que el órgano que lo represente cuente con plena competencia para resolver los conflictos y controversias relacionados a la interpretación en la aplicación del derecho de la integración. Toda restricción o limitación, tratándose de un órgano destinado a resolver los conflictos y controversias, es de todo punto de vista injustificable, como es el caso de las opiniones consultivas, que podrían perfectamente ser vinculantes, de modo tal que por medio de las resoluciones el TPR contribuya a afirmar el derecho del MERCOSUR." RUIZ DÍAZ LABRANO, Roberto. Evolución institucional del MERCOSUR: un tribunal permanente arbitral o jurisdiccional para el MERCOSUR. In: MOLINA DEL POZO, Carlos Francisco (Dir.) Evolución histórica y jurídica de los procesos de integración en la Unión Europea y en el MERCOSUR. Liber Amicorum Miguel Ángel Ciuro Caldani. Buenos Aires: Eudeba, 2011. p. 358-359.

78 PEROTTI, Alejandro Daniel. Tribunal Permanente de Revisión y estado de derecho en el MERCOSUR. Buenos Aires: Marcial Pons de Argentina, 2008. p. 81. de controvérsias, sobretudo no que diz respeito à interpretação e aplicação uniformes das normas regionais nos diferentes Estados Partes, por meio da questão prejudicial e da opinião consultiva. Como decorrência do exposto, é possível sustentar que o objetivo econômico buscado pelo bloco, aliado ao nível de aprofundamento da integração, influenciam a maneira como são solucionadas as controvérsias surgidas em seu âmago, uma vez que, quanto mais segurança jurídica e estabilidade se dá ao Direito da Integração, mais compromisso econômico se solidifica entre os Estados Partes.

A partir do estudo do desenvolvimento da UE (paradigma no tema da integração regional, cujas origens remontam à década de 1950), verifica-se que seu sistema jurisdicional de solução de controvérsias, pautado pela característica da supranacionalidade, desempenha um papel de protagonismo no sentido de interpretar, consolidar, uniformizar e até mesmo inovar o Direito da União, por meio da conformação de sua jurisprudência. Principalmente a partir das decisões proferidas em sede prejudicial, o Direito da UE pôde consolidar os princípios da primazia, do efeito direto e da aplicabilidade imediata, aplicados até hoje, surgidos com base na atuação do próprio TJ/UE. Em outras palavras, através da interpretação conferida pelo Tribunal às normas do bloco, puderam ser erigidas as bases jurídicas e econômicas que criaram a união aduaneira, que evoluiu para o mercado comum e que hoje buscam manter e expandir a união econômica e monetária.

Dessa forma, em análise comparativa com o sistema de solução de controvérsias do MERCOSUL, de caráter provisório, intergovernamental e arbitral, detectou-se que este apresenta diversos entraves ao desempenho de função similar, uma vez que traz consigo fragilidades tanto de ordem institucional quanto jurisdicional. Essas restrições acabam refletindo na atuação do TPR, que fica "acorrentado" à intergovernamentalidade, nas suas decisões, mesmo considerando ser primordial ao aprofundamento da integração econômica o reconhecimento dos três princípios antes referidos, criados a partir da atuação do TJ/UE. Em que pese essa limitação, o TPR, em sede consultiva, já se manifestou no sentido da primazia do Direito do MERCOSUL sobre o direito nacional.

Entretanto, sem perder de vista que o MERCOSUL é circundado por condições históricas, socioeconômicas e políticas que lhe são inerentes, de modo que não 
é plausível trasladar as soluções da realidade europeia, é pertinente a sugestão de mudanças pontuais na conformação do sistema implementado pelo Protocolo de Olivos, aprovado em 2002.

À vista disso, sugere-se uma superação das vulnerabilidades institucionais impostas ao TPR, por meio da aquisição de autonomia orçamentária. Relativamente à sua jurisdição, recomenda-se a exclusão da possibilidade estendida aos Estados Partes de demandarem em outros foros aspectos que possam estar vinculados ao Direito do MERCOSUL.

No que diz respeito à competência consultiva do TPR, tendo em vista a importância do instituto similar no ordenamento europeu, propõe-se uma aproximação e maior cooperação entre as jurisdições dos Estados Partes e o tribunal referido, por meio da extensão da legitimidade direta para a solicitação de opiniões consultivas aos magistrados nacionais de instâncias inferiores. Ademais, favorecendo a segurança jurídica essencial ao desenvolvimento do bloco econômico, preconiza-se tornar a sua solicitação obrigatória, bem como vincular as jurisdições nacionais ao pronunciamento do TPR em sede consultiva, garantindo-se, assim, a coesão do ordenamento jurídico do MERCOSUL.

\section{REFERÊNCIAS}

ARRUDA, Elisa. As opiniões consultivas do Tribunal Permanente de Revisão do MERCOSUL e o caso Renault do Brasil S.A. Revista Iberoamericana de Derecho Internacional y de la Integración, Buenos Aires, n. 7, Dic. 2017. Disponível em: <http://www.ijeditores.com.ar/pop.ph p?option $=$ articulo $\&$ Hash $=\mathrm{e} 7 \mathrm{~d} 965040 \mathrm{a} 8 \mathrm{a} 58112249 \mathrm{bafc}$ 497e21dc>. Acesso em: 25 fev. 2018.

BARRAL, Welber. O Protocolo de Olivos e o MERCOSUL. 2010. Disponível em: <https://periodicos.ufsc.br/index.php/sequencia/article/view/15336>. Acesso em: 20 out. 2017.

BORCHARDT, Klaus-Dieter. $O A B C$ do direito da União Europeia. Luxemburgo: Serviço de Publicações da União Europeia, 2011.

CAMPOS, João Mota de; CAMPOS, João Luiz Mota de. Manual de direito europeu: o sistema institucional, a ordem jurídica e o ordenamento económico da União Europeia. 6. ed. Coimbra: Wolters Kluwer, 2010.
CICCO FILHO, Alceu José; LAGE, Fernanda Carvalho; ROCHA, Maria Elizabeth Guimarães Teixeira. O Tribunal Permanente de Revisão do MERCOSUL: intergovernamentalidade e desafios à supranacionalidade. International Studies on Law and Education, São Paulo, v. 1, p. 55-70, set./dez. 2016.

CORREIA, Emanuella Chagas Jaguar. Efeito vinculante do reenvio prejudicial na União Europeia: um caminho para desenvolver o direito comunitário. Revista da Secretaria do Tribunal Permanente de Revisão, Assunção, n. 4, p. 65-82, ago. 2014.

DIZ, Jamile Bergamaschine Mata; JAEGER JUNIOR, Augusto. Por uma teoria jurídica da integração regional: a inter-relação direito interno, direito internacional público e direito da integração. Revista de Direito Internacional UNICEUB, Brasília, v. 12, n. 2, p. 138-158, 2015.

FEIJÓ, Camilla de Freitas. O atual sistema de solução de controvérsias do MERCOSUL: rumo à consolidação de um tribunal regional. Revista de Direito Internacional UNICEUB, Brasília, v. 9, n. 1, p. 69-89, 2012.

FONTOURA, Jorge. A construção jurisprudencial do direito comunitário europeu. Revista de Informação Legislativa, n. 140, p. 163-170, 1998.

GOMES, Eduardo Biacchi. Blocos econômicos: solução de controvérsias. 3. ed. Curitiba: Juruá, 2010.

GOMES, Eduardo Biacchi. Integração econômica no MERCOSUL: opiniões consultivas e a democratização no acesso ao Tribunal Permanente de Revisão. Revista de Direito Internacional UNICEUB, Brasília, v. 10, n. 1, p. 128-136, 2013.

GOMES, Eduardo Biacchi. La democratización del acceso al Tribunal Permanente de Revisión del MERCOSUR a través de las opiniones consultivas. Revista da Secretaria do Tribunal Permanente de Revisão, Assunção, n. 4, p. 49-63, ago. 2014.

GOMES, Eduardo Biacchi. Protocolo de Olivos: alterações no sistema de soluções de controvérsias do MERCOSUL e perspectivas. Revista da Faculdade de Direito UFPR, Curitiba, v. 37, p. 157-167, 2002.

JAEGER JUNIOR, Augusto. Metodologia jurídica europeia e mercosulista: considerações fundamentais. Revista da Secretaria do Tribunal Permanente de Revisão, Assunção, n. 3, p. 117-157, mar. 2014.

KEGEL, Patrícia Luíza; AMAL, Mohamed. Instituições, direito e soberania: a efetividade jurídica nos pro- 
cessos de integração regional nos exemplos da União Europeia e do MERCOSUL. Revista Brasileira de Politica Internacional, Brasília, v. 52, n. 1, p. 53-70, 2009.

LAUREANO, Abel. O efeito directo do direito da União Europeia: uma visão condensada do enquadramento duma preeminente criação jurisprudencial. Revista da Faculdade de Direito UFPR, n. 57, p. 113-143, 2013.

NASSER, Salem Hikmat. Direito global em pedaços: fragmentação, regimes e pluralismo. Revista de Direito Internacional UNICEUB, Brasília, v. 12, n. 2, p. 98-137, 2015.

NEGRO, Sandra C.; VIEIRA, Luciane Klein. Transformaciones en la integración regional: Venezuela y el sistema de solución de diferencias del MERCOSUR. In: ASTRID UZCÁTEGUI, María Inés de Jesús. Venezuela ante el MERCOSUR. Caracas: Academia de Ciencias Políticas y Sociales/Universidad de los Andes/Universidad Católica Andrés Bello, 2014. p. 189-206. v. 2.

PEROTTI, Alejandro Daniel. Elementos básicos para la constitución de un Tribunal de Justicia del MERCOSUR: la reforma institucional del MERCOSUR, 2008. Disponível em: <http://www.stf.jus.br/arquivo/cms/sextoEncontroConteudoTextual/anexo/Texto_dos_Exposiotres/ Elementos_basicos_para_la_constitucion_Alejandro_ Perotti.pdf>. Acesso em: 25 fev. 2018.

PEROTTI, Alejandro Daniel. Tribunal Permanente de Revisión y Estado de Derecho en el MERCOSUR. Buenos Aires: Marcial Pons de Argentina, 2008.
RUIZ DÍAZ LABRANO, Roberto. Evolución institucional del MERCOSUR: un tribunal permanente arbitral o jurisdiccional para el MERCOSUR. In: MOLINA DEL POZO, Carlos Francisco (Dir.) Evolución histórica y jurídica de los procesos de integración en la Unión Europea y en el MERCOSUR. Liber Amicorum Miguel Ángel Ciuro Caldani. Buenos Aires: Eudeba, 2011. p. 345-361.

SALDANHA, Jânia Maria Lopes. Cooperação Jurisdicional. Reenvio prejudicial: um mecanismo de direito processual a serviço do direito comunitário. Perspectiva para sua adoção no MERCOSUL. Porto Alegre: Livraria do Advogado, 2001.

VASCONCELOS, Raphael Carvalho; TAVARES, Sergio Maia. A competência consultiva do Tribunal Permanente de Revisão do MERCOSUL: legitimidade e objeto. Revista da Secretaria do Tribunal Permanente de Revisão, Assunção, v. 4, p. 117-134, ago. 2014.

VIEIRA, Luciane Klein. Interpretação e aplicação uniforme do direito da integração: União Europeia, Comunidade Andina, Sistema da Integração Centro-Americana e MERCOSUL. Curitiba: Juruá, 2013.

VIEIRA, Luciane Klein. La Hipervulnerabilidad del consumidor transfronterizo y la función material del derecho internacional privado. Buenos Aires: La Ley, 2017.

VIEIRA, Luciane Klein; MARTINS FILHO, Marcos Simões. As opiniões consultivas do MERCOSUL solicitadas pelo Poder Judiciário brasileiro. Revista dos Tribunais, São Paulo, v. 931, p. 217-236, maio 2013. 
Para publicar na Revista de Direito Internacional, acesse o endereço eletrônico www.rdi.uniceub.br ou www.brazilianjournal.org.

Observe as normas de publicação, para facilitar e agilizar o trabalho de edição. 